\title{
Articles
}

\section{CHOICE OF LAW IN FEDERAL COURTS: FROM ERIE AND KLAXON TO CAFA AND SHADY GROVE}

Kermit Roosevelt III

\begin{abstract}
Erie is one of our canonical cases. Everyone agrees that it is important, but that is about all they agree on. Different understandings of Erie abound, and Erie analysis is notoriously complex and confusing. This Article offers a simpler way to approach the Erie problem: a choice-of-law methodology I call the two-step model. It shows how Erie appears somewhat more straightforward when viewed from the choice-of-law perspective, and how the two-step model solves some of the most notorious Erie problems. Beyond the payoff in terms of clarifying choice-of-law analysis in federal courts, the model's success in this context should serve as an advertisement for its use in choice of law more generally.
\end{abstract}

AUTHOR-Professor of Law, University of Pennsylvania Law School; Chair, AALS Section on Conflict of Laws. Thanks to Stephen Burbank, Allan Erbsen, Michael Steven Green, Jill Hasday, Herma Hill Kay, Andy Koppelman, Larry Kramer, Shelley Murphey, James Pfander, Nancy Staudt, Catherine Struve, Jennifer Wallace, Tobias Wolff, and workshop participants at Northwestern University School of Law and Minnesota Law School. A version of this paper was presented at the AALS Annual Meeting in January 2011. 


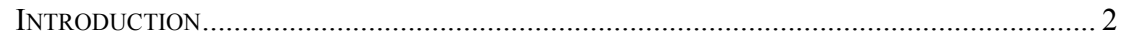

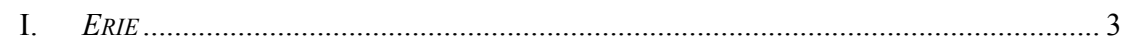

A. The Lower Courts and the General Law ...................................................... 3

B. The Supreme Court and the Constitution .......................................................... 6

C. The Erie Problem and Choice of Law ................................................... 10

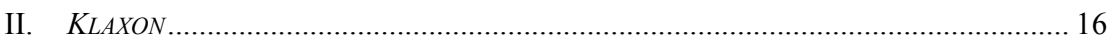

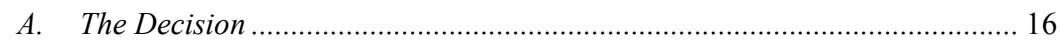

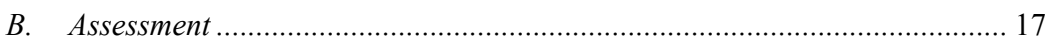

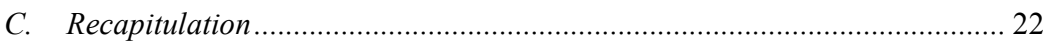

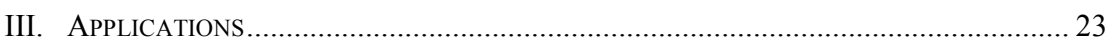

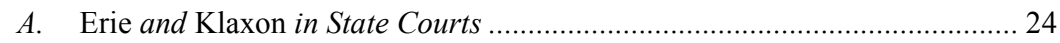

B. Van Dusen, Ferens, and Characterization .................................................... 27

C. Erie's Progeny: Why the Source of Federal Law Matters............................. 34

D. The Class Action Fairness Act ................................................................... 40

E. Shady Grove v. Allstate ...................................................................... 50

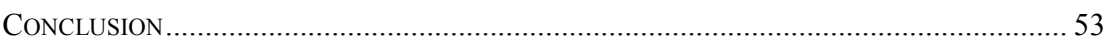

\section{INTRODUCTION}

Everyone agrees that Erie Railroad v. Tompkins is an important case. ${ }^{1}$ And at a high level of generality, everyone also agrees on what the case stands for: federal courts exercising diversity jurisdiction apply federal procedure but state substantive law. ${ }^{2}$ Dig any deeper than that, though, and the agreement dissolves. ${ }^{3}$

In fact, Erie analysis is notorious for the puzzles it has produced. Does the case have any import for state courts? What happens when a federal court transfers a case to a district in another state? How should federal common law created to fill gaps in the Federal Rules of Civil Procedure interact with state law deemed substantive for Erie purposes? Does the Constitution require federal courts to follow state choice-of-law rules? Or might they have the power to modify such rules in the context of a class action?

\footnotetext{
1304 U.S. 64 (1938). See Charles Alan Wright \& Mary Kay Kane, LAW OF FEDERAL Courts $\S 55$, at 378 (6th ed. 2002) ("It is impossible to overstate the importance of the Erie decision."); Craig Green, Repressing Erie's Myth, 96 CALIF. L. REV. 595, 595 (2008) (describing Erie as one of the "cultural pillars of our legal architecture").

${ }^{2}$ See, e.g., Rex R. Perschbacher \& Debra Lyn Bassett, The Revolution of 1938 and Its Discontents, 61 OKLA. L. Rev. 275, 276 (2008) (offering this characterization); Amanda R. Szuch, Comment, Reconsidering Contractual Waivers of the Right to a Jury Trial in Federal Court, 79 U. CIN. L. REv. 435, 442-43 (2010) (same).

3 See, e.g., Alfred Hill, The Erie Doctrine and the Constitution, 53 Nw. U. L. REV. 427, 427 (1958) (noting "extraordinary confusion" surrounding Erie).
} 
The Supreme Court has offered answers to some of these questions, ${ }^{4}$ but the Justices have usually differed amongst themselves, and their work has received mixed reviews. ${ }^{5}$ My aim in this Article is to provide a better way of thinking about the Erie problem.

That better way is a conceptual framework developed in the choice-oflaw context, what I will call the "two-step model." It is appropriate for Erie analysis because, I will argue, Erie is in fact best understood as a choice-oflaw case. Part I of this Article will present that argument by engaging in a close reading of Erie to show that its conceptual structure is the same as that of the classic choice-of-law problem. Parts II and III then demonstrate that the understanding of Erie achieved by viewing it through the two-step model gives us new insight into some difficult problems, both classic Erie puzzles and more recent choice-of-law conundrums.

But solving those problems is not my sole or final goal. I have argued in other publications that this model is the correct way to conceptualize choice-of-law problems, but it is by no means universally accepted in that context. ${ }^{6}$ I hope that its success in resolving some of these problems will serve as an advertisement for its use in choice of law more generally. I hope to show, that is, that Erie is fundamentally a choice-of-law case, that we can deal with the problems it creates by using the two-step model, and that the model's success suggests that it is indeed the correct way to think about choice of law.

\section{ERIE}

\section{A. The Lower Courts and the General Law}

One dark night, Pennsylvania resident Harry Tompkins was walking alongside the tracks of the Erie Railroad in Hughestown, Pennsylvania when he was struck and knocked down by an object-probably the swinging door of a refrigerator car-protruding from a passing train. ${ }^{7}$ As he

\footnotetext{
${ }^{4}$ See, e.g., Klaxon Co. v. Stentor Elec. Mfg. Co., 313 U.S. 487, 496 (1941) (holding that federal courts exercising diversity jurisdiction must apply state choice-of-law rules); Ferens v. John Deere Co., 494 U.S. 516, 519 (1990) (holding that interdistrict transfer should not affect choice of law).

${ }^{5}$ See, e.g., Thomas D. Rowe, Jr., Not Bad for Government Work: Does Anyone Else Think the Supreme Court Is Doing a Halfway Decent Job in Its Erie-Hanna Jurisprudence?, 73 NOTRE DAME L. REV. 963 (1998).

${ }^{6}$ See, e.g., Kermit Roosevelt III, Resolving Renvoi: The Bewitchment of Our Intelligence by Means of Language, 80 Notre DAME L. REV. 1821, 1861-64 (2005) [hereinafter Roosevelt, Renvoi]; Kermit Roosevelt III, The Myth of Choice of Law: Rethinking Conflicts, 97 MiCH. L. REv. 2448, 2450 (1999) [hereinafter Roosevelt, Myth].

${ }^{7}$ For a detailed recounting of the facts of Erie, see Edward A. Purcell, Jr., The Story of Erie: How Litigants, Lawyers, Judges, Politics, and Social Change Reshape the Law, in CIVIL Procedure StORIES 21, 35-38 (Kevin M. Clermont ed., 2d. ed. 2008). See also Tompkins v. Erie R.R., 90 F.2d 603, 604 (2d Cir. 1937).
} 
fell, his right arm went under the wheels of the train. ${ }^{8}$ Most of the arm was severed, and the remainder was later amputated by doctors. ${ }^{9}$ Tompkins sued the railroad in federal district court in New York, claiming the railroad had been negligent in allowing the door to swing open. ${ }^{10}$

A crucial question was the duty the railroad owed to Tompkins, who was a trespasser on its right-of-way. Pennsylvania courts had ruled that for pedestrians on a path parallel to the tracks (as opposed to a crossing), the railroad had a duty only "to refrain from willful or wanton injury." 11 The railroad relied on these cases. Tompkins argued, and the railroad conceded, that "the great weight of authority in other states [was] to the contrary," imposing an ordinary negligence standard. ${ }^{12}$

What law should determine the duty of care? Although Erie analysis is now concerned with whether federal or state law should be applied, Erie itself did not present a choice between state and federal law. No one argued that federal law should control. There was no federal law setting the duty of care (although given that the case concerned a railroad, there could have been), and the Rules of Decision Act provided that in the absence of federal law, the "laws of the several states" should govern. ${ }^{13}$ Nor did it present a choice between state laws; no one argued that the law of any state other than Pennsylvania should determine the duty of care. The key question was whether it was an issue of local or of general law. ${ }^{14}$

To understand this distinction, we need to return to the analytical framework that the district court and Second Circuit used, the one canonically associated with, though not created by, Swift v. Tyson. ${ }^{15}$ Under the Swift framework, there were essentially three types of law. First, there was federal law: the Constitution, federal statutes, and treaties. ${ }^{16}$ This law was created by the federal government, or by the National People in the case of the Constitution, and federal courts were supreme in its interpretation. Second, there was state law, consisting of state constitutions, state statutes, and decisions of state courts on some common law matters deemed "local"- typically issues such as rights to real property within the

\footnotetext{
${ }^{8}$ Purcell, supra note 7, at 38.

${ }^{9}$ Id.

${ }^{10} I d$. at $39,40$.

11 Tompkins, 90 F.2d at 604 (citing Falchetti v. Pa. R.R., 160 A. 859 (Pa. 1932)) (noting the defendant's argument that this was the current local law under Falchetti, but ultimately deciding that "we need not go into this matter"); see also Koontz v. Balt. \& Ohio R.R., 163 A. 212 (Pa. 1932).

12 Tompkins, 90 F.2d at 604.

13 See Swift v. Tyson, 41 U.S. (16 Pet.) 1, 18 (1842) (quoting Judiciary Act of 1789, ch. 20, § 34, 1 Stat. 73, 92 (codified as amended at 28 U.S.C. $§ 1652(2006)$ )).

${ }^{14}$ See Tompkins, 90 F.2d at 604 (deciding that issue was one of general rather than local law).

1541 U.S. 1; see Guaranty Trust Co. v. York, 326 U.S. 99, 102 (1945) (observing that Swift "did not enunciate novel doctrine").

${ }^{16}$ See U.S. ConsT. art. VI, § 2 (identifying types of federal law).
} 
state. ${ }^{17}$ This law was made by state governments and state courts were its authoritative interpreters. (Thus, for instance, both federal courts and courts of other states would defer to the interpretation of a state statute given by that state's court of last resort.) Last, and oddest to the modern eye, there was general law. General law included most of the classic common law subjects of tort and contract. ${ }^{18}$ It was not created by any government, but rather deduced by judges. ${ }^{19}$ And because it was not the creation of any particular government, no court could claim to be authoritative in its interpretation. Federal courts could come to their own conclusions about the content of the general common law, and so could the courts of the several states, with neither exerting any more than persuasive influence on any other. ${ }^{20}$

At the time Erie was filed, both the district court and the Second Circuit had ruled that the duty of care owed by a railroad to a trespasser on its property was a question of general law. ${ }^{21}$ The railroad, of course, disagreed, and its contrary contention formed the primary part of its argument to the Supreme Court. ${ }^{22}$ But assuming that the lower courts were correct as to the characterization as general law, what should the result have been under the Swift framework? Had Tompkins sued in Pennsylvania, he would have gotten the Pennsylvania courts' view of the correct answer under the general law: the "willful or wanton" standard. A New York state court would have given him its own independent understanding: apparently the negligence standard that most states used. ${ }^{23}$ And if Tompkins had chosen a federal court (as he did), that court, no matter where it was

\footnotetext{
17 See Swift, 41 U.S. at 18 (describing local issues as those relating to things "immovable and intraterritorial in their nature and character").

18 See Edward A. Purcell, Jr., Ex Parte Young and the Transformation of the Federal Courts, 18901917, 40 U. TOL. L. REV. 931, 947 (2009) ("[B]y the late nineteenth century the federal courts had stretched the 'general' law to include most common-law fields, including wills, contracts, torts, deeds, mortgages, rules of evidence, and measures of damages.").

${ }^{19}$ See, e.g., Balt. \& Ohio R.R. v. Baugh, 149 U.S. 368, 378 (1893) ([G]eneral law . . . does not depend upon any statute, it does not spring from any local usage or custom ... but it rests upon those considerations of right and justice which have been gathered into the great body of the rules and principles known as the "common law."'); Jay Conison, What Does Due Process Have to Do with Jurisdiction?, 46 RUTGERS L. REV. 1071, 1159-60 (1994) (quoting Baugh, and describing the deductive nature of judicial reasoning).

20 See generally Kermit Roosevelt III, Light from Dead Stars: The Procedural Adequate and Independent State Ground Reconsidered, 103 COLuM. L. REV. 1888, 1896-97 (2003) (describing independent interpretation of general law).

${ }^{21}$ See Tompkins v. Erie R.R., 90 F.2d 603, 604 (2d Cir. 1937) (citing cases).

22 See Brief for Petitioner at 23-25, Erie R.R. v. Tompkins, 304 U.S. 64 (1938) (No. 367), 1938 WL 35347 , at *23-25. The brief does not make a frontal attack on Swift, but instead argues that courts have misapplied the doctrine, which should distinguish between local and general issues primarily by the criterion of whether state courts have established a firm rule.

23 See N.Y., New Haven \& Hartford R.R. v. Kmetz, 193 F. 603, 606 (2d Cir. 1912).
} 
located, would also have given its independent interpretation of the general law.

Tompkins knew this, of course, which is why he chose federal court: forum shopping is law shopping, and he wanted the federal understanding of the general law. All went according to plan in the lower courts, but at the Supreme Court level, the case took a very different turn.

\section{B. The Supreme Court and the Constitution}

The parties, as noted above, disputed whether the railroad's duty of care was a matter of general law or of local law. The railroad argued in addition that Swift had been misconstrued, and that the local-general distinction should take into account not just the character of the issue, but also the degree to which state courts had settled on a definite rule. ${ }^{24}$ It did not ask the Court to overrule Swift.

That issue, however, was the one the Court took up in the first sentence of the opinion. "The question for decision," Justice Brandeis wrote, "is whether the oft-challenged doctrine of Swift $v$. Tyson shall now be disapproved. ${ }^{25}$ Brandeis found three grounds on which to fault Swift.

First, Swift, to some extent, was an exercise in statutory interpretation. When the Rules of Decision Act directed federal courts to use the "laws of the several states" in the absence of federal law, ${ }^{26}$ did the word "laws" include the decisions of state courts on common law matters? Swift had said no, Brandeis wrote, but "the more recent research of a competent scholar," namely Brandeis's friend Charles Warren, "established that the construction given to [the Act] by the Court was erroneous." ${ }^{27}$

Warren may or may not have been right on this point, ${ }^{28}$ but the argument about the correct interpretation of the Rules of Decision Act (I will call this "statutory Erie") would not by itself have been enough to lead the Court to overturn Swift. Stare decisis, the Court often observes, has greater force in cases of statutory interpretation, and when the Court has applied one reading of a statute for a century or more, it will take more than competent scholarship to make it change course. Erie itself says as much. ${ }^{29}$

The second problem was that Swift had turned out to work rather poorly in practice. The fact that federal courts were not bound to follow

\footnotetext{
${ }^{24}$ See Brief for Petitioner, supra note 22, at 24-25.

25 Erie R.R. v. Tompkins, 304 U.S. 64, 69 (1938) (footnote omitted).

26 See supra note 13 and accompanying text.

27 Erie, 604 U.S. at 72-73 \& n.5 (citing Charles Warren, New Light on the History of the Federal Judiciary Act of 1789, 37 HARV. L. REV. 49, 51-52, 81-88, 108 (1923)).

${ }^{28}$ See Stephen B. Burbank, Interjurisdictional Preclusion, Full Faith and Credit and Federal Common Law: A General Approach, 71 CoRnell L. Rev. 733, 760 \& n.117 (1986); Green, supra note 1 , at 600 n.23.

${ }^{29}$ See Erie, 304 U.S. at 77 ("If only a question of statutory construction were involved, we should not be prepared to abandon a doctrine so widely applied throughout nearly a century.").
} 
state courts on matters of general law meant that there were frequently two different rules of law in force inside a single state, either of which was available to a party able to get into federal court. The strategic invocation of federal jurisdiction produced a predictable set of horror stories, ${ }^{30}$ and the resultant uncertainty proved more generally undesirable. ${ }^{31}$

Viewed with the benefit of hindsight, the Swift regime seems misguided. But things might have turned out much better. The aim, or at least the hope, of the Swift approach was presumably that the federal interpretation of the general law would win acceptance in state courts. ${ }^{32}$ If this occurred, the result would be law that was uniform not only within a single state but across the whole nation - a very desirable consequence for commercial law, Swift's subject.

Experience, Erie admits, discouraged this prophecy. "Persistence of state courts in their own opinions on questions of common law prevented uniformity; and the impossibility of discovering a satisfactory line of demarcation between the province of general law and that of local law developed a new well of uncertainties." ${ }^{33}$ So the second aspect of Erie (I will call this "policy Erie") is the desire that a federal court exercising diversity jurisdiction be, for practical purposes, "only another court of the State," as Felix Frankfurter put it. ${ }^{34}$ Swift had thwarted this policy, and Brandeis hoped to further it.

This policy concern would for some have been a sufficient reason to overturn Swift. But Erie declined to rest on the policy argument, deeming it an inadequate justification to "abandon a doctrine so widely applied throughout nearly a century." ${ }^{35}$ Instead, Erie turned to a third problem with Swift: "the unconstitutionality of the course pursued," Brandeis wrote, "has now been made clear and compels us to [abandon it]." ${ }^{36}$ Thus, according to Brandeis, there is also a third, constitutional, basis for the decision (I will call this "constitutional Erie"). ${ }^{37}$ But what is it?

\footnotetext{
30 Likely the most famous is Black \& White Taxicab \& Transfer Co. v. Brown \& Yellow Taxicab \& Transfer Co., 276 U.S. 518 (1928), where a taxi company reincorporated under another state's law in order to create diversity jurisdiction. Id. at 523-24.

31 Erie, 304 U.S. at 74.

32 See id. ("[T] he benefits expected to flow from the rule [in Swift] did not accrue.").

33 Id. (footnote omitted).

34 Guaranty Trust Co. v. York, 326 U.S. 99, 108 (1945).

35 Erie, 304 U.S. at 77.

36 Id. at 77-78.

37 The availability of the alternative ground of policy explains why it was at one time "fashionable" to call the constitutional argument dictum. John Hart Ely, The Irrepressible Myth of Erie, 87 HARV. L. REV. 693, 702 n.59 (1974). But that practice was apparently ended by Alfred Hill's trenchant observation that "it is difficult to view as dictum the Court's statement of a legal proposition without which, we are assured in the opinion, and have no reason to doubt, the case would have been decided the other way." Hill, supra note 3, at 439.
} 
There is a surprising amount of disagreement about Erie's constitutional source. ${ }^{38}$ But the basic outline should be relatively clear. The main move that constitutional Erie makes - the fulcrum on which all else turns - is to deny the existence of the general law. Swift's "fallacy," Brandeis says, quoting Justice Holmes, is

the assumption that there is "a transcendental body of law outside of any particular State but obligatory within it unless and until changed by statute," that federal courts have the power to use their judgment as to what the rules of common law are; and that in the federal courts "the parties are entitled to an independent judgment on matters of general law"-: "but law in the sense in which courts speak of it today does not exist without some definite authority behind it. The common law so far as it is enforced in a State, whether called common law or not, is not the common law generally but the law of that State existing by the authority of that State ...."39

So Erie's central claim is that the idea of general law, produced by no sovereign and hence possessing no authoritative interpreter, is simply specious. "There is no federal general common law," Brandeis wrote $\mathrm{e}^{40}-\mathrm{a}$ slight imprecision, because what he meant was that there was no general law at all. The rules that courts applied in diversity cases could not be drawn from what Holmes derided as a "brooding omnipresence in the sky." 41 They had to come from some government, either state or federal.

As I have already said, no one thought these rules were federal law made by the federal government. If they had been, all the Swift-era "diversity" cases would have been federal question cases. And so the problem of intrastate disuniformity would not have arisen because the federal law would have preempted contrary state laws. Obviously, neither of these situations obtained under Swift.

Moreover, they could not be federal, for the federal government does not have a general lawmaking power; it has the specific powers the Constitution gives it. ${ }^{42}$ As Brandeis put it, "Congress has no power to declare substantive rules of common law applicable in a State whether they be local in their nature or 'general,' be they commercial law or a part of the

\footnotetext{
38 See, e.g., Bradford R. Clark, Erie's Constitutional Source, 95 CALIF. L. REV. 1289, 1289 (2007) ("The constitutional rationale of Erie Railroad Co. v. Tompkins has remained elusive for almost seventy years." (footnote omitted)).

39 Erie, 304 U.S. at 79 (quoting Black \& White Taxicab \& Transfer Co. v. Brown \& Yellow Taxicab \& Transfer Co., 276 U.S. 518, 533 (1928) (Holmes, J., dissenting)).

${ }^{40} I d$. at 78 .

41 S. Pac. Co. v. Jensen, 244 U.S. 205, 222 (1917) (Holmes, J., dissenting).

42 See, e.g., United States v. Lopez, 514 U.S. 549, 552 (1995) (defining as a "first principle[]" that "[t]he Constitution creates a Federal Government of enumerated powers" (citing U.S. CONST. art. 1, $\S 8)$ ).
} 
law of torts." ${ }^{43}$ So the general practice under Swift was unconstitutional, even though Congress, had it wanted, could have regulated in some cases. ${ }^{44}$

In any case, Congress had not exercised its regulatory power, so the only possible source of law was the states $^{45}$ - or, conceivably, the federal courts. Can federal courts make law in diversity cases without congressional direction? Here Erie scholars diverge, some assuming that the lawmaking power of the federal courts is coextensive with that of Congress and some suggesting it is likely far narrower. ${ }^{46}$ The idea that federal courts can make law at will on any issue within the scope of congressional legislative power strikes me as prima facie implausible. Congress is a politically accountable branch, one of whose houses, in the original design, was responsible directly to state legislatures, and it is quite a stretch to suppose that the Constitution implicitly vested equivalent lawmaking power in unelected and life-tenured federal judges. ${ }^{47}$

But what lawmaking power the federal courts might have in other cases is, like the reach of congressional power, beside the point as far as Erie itself is concerned. In Erie, the Supreme Court did not seem inclined make any federal common law of railroad duties of care, even if it could

${ }^{43}$ Erie, 304 U.S. at 78. Again, this is imprecise because Congress does have the power to declare many rules of law binding in a state. For example, given that Erie was about a railroad's duty of care, Congress could certainly have used its power over interstate commerce to prescribe a rule to govern that case, had it so chosen. What Brandeis presumably meant was that Congress could not legislate over the whole range of topics covered by the general law, or that the mere existence of diversity jurisdiction does not create federal lawmaking power. See, e.g., Martha A. Field, Sources of Law: The Scope of Federal Common Law, 99 HARV. L. REV. 881, 926 (1986).

${ }^{44}$ Such federal law would, however, have created federal question jurisdiction and presumably preempted contrary state law, so the result would be federalization rather than restoration of Swift's independent state and federal interpretation.

${ }^{45}$ What the content of this state law might be is a separate question. Erie affirmed that state courts were authoritative in the interpretation of their own law. See Erie, 304 U.S. at 78 ("[W]hether the law of the State shall be declared by its Legislature in a statute or by its highest court in a decision is not a matter of federal concern."). Michael S. Green has explored the possibility that the Swift approach might be permissible if state courts announced that their interpretations of state law were not to be taken as authoritative. Michael Steven Green, Erie's Suppressed Premise, 95 MinN. L. REv. 1111, 1121-35 (2011). The idea is intriguing, but I am not persuaded that state courts actually understood the Swift-era practice in this light. Brandeis and the Justices in the majority clearly did not; they saw it as resting on the existence of a general common law created by no sovereign and in whose interpretation no court could be authoritative.

46 See Clark, supra note 38 (describing the dispute).

47 See id. at 1302-06 (describing political safeguards of federalism governing federal legislation). On the other hand, the founding generation's understanding of common law differed from ours, so originalist arguments may be of little use in this area. See Larry Kramer, The Lawmaking Power of the Federal Courts, 12 PACE L. REv. 263, 279-284 (1992) ("Although the historical background generally supports the claim that federal judges can make common law, I would not rely on it for too much guidance. One problem is that what it means today to say that judges have common law powers is totally different from what it meant to say this in the 18th and early 19th centuries.”). I think Kramer's general view is right: federal courts can make law whenever necessary (i.e., in exclusively federal enclaves) or when necessary and proper to implement a statute. See id. at 288. 
have. With no federal lawmaking power exercised, there was no federal law on point, so the only alternative was state law. ${ }^{48}$ Continuing to follow Swift once the existence of general law was disavowed would be to exercise the coercive power of the federal courts without any law to justify it. ${ }^{49}$

\section{The Erie Problem and Choice of Law}

Where does this leave us? Erie has a statutory basis that counts for little, a policy basis that is obvious but-according to the Courtinsufficient to produce the decision, and a constitutional ground that is also pretty obvious. If there is no federal law on point (and leaving aside the disagreements about whether there could be in various cases), a federal court must apply state law because that is the only law that could be operative. To state the principle more generally, constitutional Erie tells us that if only one law reaches the facts of a case, that law must supply the rule of decision. ${ }^{50}$

To those experienced with choice of law, this principle may have a familiar ring: it is essentially Brainerd Currie's analysis of "false conflicts." ${ }^{51}$ But a little more explanation is in order to show that Erie is actually a choice-of-law case.

A choice-of-law problem, to put it generally, arises when there is more than one sovereign whose law might create rights or obligations related to a particular event. ${ }^{52}$ Scholars and courts have come up with a dizzying array of methodologies to choose which law should be used to decide such cases..$^{53}$ Despite their creativity — or, more likely, because of it - the field is widely regarded as a conceptual disaster. ${ }^{54}$

\footnotetext{
48 Since no one thought that the general law was federal law, Erie does not actually limit the scope of federal lawmaking authority. Instead, it expands the scope of state lawmaking by announcing that what had been thought general law is in fact state law.

49 What is the constitutional problem with doing that? Sourcing Erie to a particular constitutional provision is notoriously difficult, and it is not my main purpose here. I will only suggest, without attempting a full defense of the claim, that the Due Process Clause, which protects against state coercion "without ... law" is the best candidate. U.S. CONST. amend. V.

${ }^{50}$ Erie also has some other propositions that sound constitutional in nature-for instance, that a state's law is what that state's courts say it is, not what someone else might think is a good idea. See Erie, 304 U.S. at 78 ("[W]hether the law of the State shall be declared by its Legislature in a statute or by its highest court in a decision is not a matter of federal concern.").

51 See generally Brainerd Currie, Selected Essays on the Conflict of Laws (1963) (creating a taxonomy of choice-of-law cases, including "true conflicts," "false conflicts," and "unprovided-for cases").

52 See Kermit Roosevelt, III, Conflict of Laws 1 (2010).

${ }^{53}$ See id. at 3-105 (explaining traditional and modern approaches).

54 See, e.g., Lawrence Lessig, The Zones of Cyberspace, 48 STAN. L. REV. 1403, 1407 (1996) (“[C]onflicts of law is dead-killed by a realism intended to save it.").
} 
A better way to approach a choice-of-law problem, I and others have suggested ${ }^{55}$ is via what I call the two-step model. The first task for a court in a choice-of-law case is to determine which sovereigns might attach legal consequences to the events and which have in fact done so. This is a matter of interpreting the sovereigns' laws to determine their scope. If more than one law reaches the facts of the case and the rights they create conflict, the court must proceed to a second step: it must decide which of the competing rights will get priority. If, however, only one law creates rights or obligations, that law will - indeed, must - supply the rule of decision.

That principle, of course, is the same one I just identified as constitutional Erie. So it should seem prima facie plausible that the model that generates this principle (and hence resolves Erie on its facts) might also be a useful way to approach more difficult Erie problems.

Of course, this is not the path that Erie analysis has taken. The conventional statement of the basic rule - that federal courts exercising diversity jurisdiction apply state substantive law but federal proceduresuggests that the task is essentially one of characterization: courts must decide whether a particular issue is substantive or procedural. ${ }^{56}$ But the Supreme Court soon recognized that trying to draw this distinction in some abstract sense was a poor way to proceed. ${ }^{57}$ Policy Erie - the desire to avoid forum shopping-led the Court in Guaranty Trust v. York to say that some laws deemed procedural by the state that created them (a limitations period in Guaranty Trust itself) would nonetheless be considered substantive for Erie purposes and hence given effect in federal court if they were outcomedeterminative.

Guaranty Trust's analysis implied that substance and procedure were not stable and mutually exclusive categories because a law could be procedural in the view of state courts and yet substantive under Erie. Further, the converse was also possible: a law that the state deemed substantive might address the same issue as, and therefore overlap with, a federal procedural rule. Sometimes, the Court hinted in Byrd v. Blue Ridge Rural Electrical Cooperative, such a law might be so substantive that the

\footnotetext{
55 Brainerd Currie's interest analysis is probably the first self-conscious development of a two-step approach to choice of law in American scholarship. See CURRIE, supra note 51, at 183-84 (setting out a two-step process of identifying interested states and resolving cases accordingly). Larry Kramer refined Currie's approach. Larry Kramer, Return of the Renvoi, 66 N.Y.U. L. REv. 979, 982 (1991) (describing the two-step approach). This Article is part of my attempt to carry the project further. See generally ROOSEVELT, supra note 52 (offering an analytical overview of conflict of laws from a two-step perspective).

56 See, e.g., Armando Gustavo Hernandez, The Head-on Collision of Gasperini and the Derailment of Erie: Exposing the Futility of the Accommodation Doctrine, 44 CREIGHTON L. REv. 191, 199 n.51 (2010).

57 See Guaranty Trust Co. v. York, 326 U.S. 99, 109 (1945).
} 
federal court would have to give it effect. ${ }^{58}$ Other times the federal procedural rule might be followed. ${ }^{59}$ Subsequent cases would show that whether the court applied state or federal law depended not just on how substantive the state law was, but also on whether the federal rule was one of the Federal Rules of Civil Procedure or judge-made law created to fill gaps in the rules. ${ }^{60}$ Erie analysis, as taught to generations of first-year students, follows an ever more complicated flowchart, where surprising twists and turns abound. ${ }^{61}$

What if we think about Erie as a choice-of-law problem instead, using the two-step model ${ }^{62}$ Things turn out to be somewhat simpler. The court's task, remember, is first to determine the scope of the different sovereigns' laws, and then to assign priority to one or the other if conflicts exist.

Erie itself is easy to understand from this perspective. With the general law out of the picture, the question of the railroad's duty of care fell within the scope of only one sovereign's law (Pennsylvania's); of course its law would govern. Erie analysis, the more general choice between federal and state law, can also be described within the two-step model. First, the court must decide whether federal law or state law grants rights to the parties, or whether both laws do-whether the case falls within the scope of the different laws. Second, if conflicting rights exist, the court must decide which will get priority - whether the federal law will preempt the state law.

What is the advantage of describing Erie analysis in this way? I hope in subsequent sections to demonstrate that it resolves several puzzles. Here I will make just a few preliminary observations.

First, thinking about the scope of laws offers us a useful way to understand the meaning and relevance of the distinction between substance and procedure. Substantive law, we could say, creates rights that can be asserted in any forum. ${ }^{63}$ Procedural law creates rights that are tied to a particular forum and cannot be asserted elsewhere. ${ }^{64}$

58356 U.S. 525, 535-36 (1958) (noting that a state rule may be so "bound up with the definition of the rights and obligations of the parties" that "its application in federal court is required").

59 See id. at 537-38 (noting that federal policy may direct application of federal law).

${ }^{60}$ Compare Hanna v. Plumer, 380 U.S. 460 (1965) (Federal Rule of Civil Procedure), with Ragan v. Merchs. Transfer \& Warehouse Co., 337 U.S. 530 (1949) (judge-made law)

${ }^{61}$ See, e.g., Rowe, supra note 5, at 990.

${ }^{62}$ For prior suggestions to view Erie from a choice-of-law perspective, see, e.g., Joseph P. Bauer, The Erie Doctrine Revisited: How a Conflicts Perspective Can Aid the Analysis, 74 Notre DAME L. REV. 1235 (1999); John R. Leathers, Erie and Its Progeny as Choice of Law Cases, 11 Hous. L. REv. 791 (1974). This Article offers the same prescription but differs by employing the two-step understanding of choice of law.

${ }^{63}$ A tort claim, for instance, is uncontroversially substantive, and it should also be uncontroversial that a tort claim based on the law of one state can be asserted in the courts of another.

64 The right to use a certain number of pages in a reply brief, for example, is uncontroversially procedural, and it is also pretty clear that one state's rule about permissible length will not govern litigation in the courts of another state. 
This definition does not give us any foolproof or mechanical way to decide whether a particular rule is substantive or procedural. We will still have to do something similar to what courts have done in the past-ask, perhaps, whether the law is designed to regulate in-court or out-of-court behavior. But it does allow us to be clear about the significance of the substance-procedure distinction and to state the problem simply. State procedural law will never be given effect in federal courts; it creates no rights that can be asserted there. State substantive law may be given effect in federal court; but it might also be displaced by conflicting federal procedural law.

That is Erie analysis as far as scope is concerned. Already, I believe, there is some payoff from the two-step model in terms of a better understanding of substance and procedure. Classically, substance and procedure were conceived of as mutually exclusive categories. ${ }^{65}$ If that is the case, one might wonder how state substantive and federal procedural law could ever overlap and conflict. One might also think that the Erie problem is simply how to decide whether a particular rule is "really" substantive or procedural.

The two-step model takes us beyond this classic formalism. Of course, modern thinking also holds that the categories are not mutually exclusive. ${ }^{66}$ But if they are not distinct conceptual boxes, what are they? Modern Erie analysis does not have a very good answer. It still leaves us with an idea of two incompletely overlapping categories and a muddy middle ground of things that might be substantive for some purposes but procedural for others.

By contrast, defining substance and procedure in terms of forumindependence and forum-dependence - that is, in terms of the scope of the laws - makes plain how they can conflict: both state substantive and federal procedural law create rights that litigants in federal court can assert. ${ }^{67}$

What about the muddy middle ground? How can something be both substantive and procedural, and how should such a hybrid be treated? If we think in terms of the scope of the rights created, these things are not

${ }^{65}$ See Hanna, 380 U.S. at 465-66 (tracking the dissolution of the "traditional or common-sense substance-procedure distinction").

${ }^{66}$ See, e.g., Thomas O. Main, The Procedural Foundation of Substantive Law, 87 WASH. U. L. REV. 801,802 (2010) ("[P]rocedure is inherently substantive ... [and] the converse is also true."). The Supreme Court recognized the point in 1945. See Guaranty Trust Co. v. York, 326 U.S. 99, 108-09 (1945).

${ }^{67}$ A state might, for instance, create a tort cause of action and give the plaintiff five years to sue on the grounds that the full extent of this particular kind of injury cannot be immediately determined. That is a justification that applies regardless of the forum; it means that the five-year period is substantive. The federal government might, however, have a rule that all tort claims must be brought within four years. This is surely a procedural rule as I have defined the term - it is intended to promote timely filing in federal court and will not operate in state courts. But in federal court, it will conflict with the substantive state right. 
mysterious either. Some rules will have both procedural and substantive (forum-dependent and forum-independent) purposes behind them. Limitations periods, at issue in Guaranty Trust, are one example. The consequence is straightforward. If there is a substantive purpose, a right can be asserted in any forum, regardless of whether there is also a procedural purpose whose scope is limited to particular courts.

But, one might ask, what about state procedural rules that are substantive for Erie purposes? In Guaranty Trust, the Supreme Court held that some outcome-determinative rules (notably including limitations periods) would be given effect in federal court even if the state that created them classed them as procedural. Such rules might seem to pose a problem for the choice-of-law-based analysis-are they not state procedural rules that are given effect in federal court, contrary to my definition of substance and procedure?

No, they are not. If a state rule is procedural in my sense, constitutional Erie tells us that it cannot be used to decide an issue in federal court. ${ }^{68} \mathrm{~A}$ federal case falls outside the scope of a state procedural rule - the state rule creates no rights that can be asserted in federal court - and so federal law must supply the rule of decision. The scope of state law is a matter of state law; a federal court lacks the power to decide that, regardless of what the state wants, the state's law will give rights to certain parties. ${ }^{69}$

What then are we to make of Guaranty Trust? There are two explanations that the choice-of-law perspective offers. First, as to the specific facts of the case itself, it is probably wrong to call limitations periods procedural. A limitations period does have a procedural purpose, which is to allocate judicial resources to the litigation of fresh rather than stale claims. And were that its only purpose, it might reasonably be classed as procedural and its assertion limited to a particular forum. But it is also intended to give defendants peace of mind after a prescribed period, and that is clearly a right intended to be conveyed regardless of forum - that is, a substantive right. It is thus no surprise that the traditional characterization

${ }^{68}$ This point may not be intuitively obvious, but further reflection should convince any skeptics. If a state statute contains explicit limits on the scope of the rights it creates, a federal court cannot disregard those limits and still claim to be enforcing a state-law right. See Byrd v. Blue Ridge Rural Elec. Coop., 356 U.S. 525, 535 (1958). This is obviously true with respect to, say, the elements of a cause of actiona federal court cannot decide to require only three when the state law has four-and no less true with regard to a limit providing that the right may be asserted only in state court, so long as that limit is constitutional.

${ }^{69}$ For example, if a state wrongful death statute limits its scope to deaths "caused in this state," a federal court surely lacks power to award recovery under it for an out-of-state accident. Some complications exist - there are presumably some rights that a state could not grant litigants in its courts but withhold from those in federal court, in just the same way that it could not withhold them from parties in the courts of other states. See Tenn. Coal, Iron \& R.R. v. George, 233 U.S. 354, 360 (1914). But those would be rights that are not even arguably procedural in the sense of governing in-court behavior. 
of limitations periods as procedural has been widely rejected by states through the enactment of borrowing statutes. ${ }^{70}$

Second, and more generally, when a federal court decides to apply a rule that a state deems procedural on the ground that it is outcomedeterminative, it is not giving state-created rights an effect that their creator disclaimed, because it lacks the power to do this. ${ }^{71}$ Rather, it is creating federal law that incorporates the substance of the state rule. Incorporation of state law is actually relatively common. ${ }^{72}$ Even when constitutional Erie tells us that federal law must supply the rule of decision because there is no state law on point, then policy Erie may suggest that the federal law should incorporate a state rule.

So the choice-of-law perspective gives us a simpler understanding of what is at stake in Erie analysis. It gives us a better account of what is going on in Guaranty Trust-type situations: in accordance with Erie's policy goal of substantial uniformity, the federal court is making federal law that tracks the law of the state in which it sits. ${ }^{73}$ In the remainder of this Article, I will try to show some other connections between Erie and choice of law.

Erie analysis can help us better see how choice of law should workErie will turn out to have implications in state courts as well as federal ones. $^{74}$ Choice-of-law analysis, in turn, can explain some of Erie's progeny - notably, it can explain why Erie analysis differs depending on the source of the federal rule. ${ }^{75}$ Putting the two together can tell us something about still other problems, such as how federal courts should deal with state choice-of-law rules in the context of the Class Action Fairness Act. ${ }^{76}$ To start, though, I will turn to Erie's most direct descendant in the realm of choice of law: Klaxon Co. v. Stentor Electric Manufacturing Co. $^{77}$

${ }^{70}$ See generally Ibrahim J. Wani, Borrowing Statutes, Statutes of Limitations and Modern Choice of Law, 57 UMKC. L. REV. 681 (1989) (discussing borrowing statutes).

71 Again, a federal court lacks power to expand the scope of a state right. Ragan v. Merchs. Transfer \& Warehouse Co., 337 U.S. 530, 533-34 (1949) (“[W]e cannot give [the cause of action] longer life in the federal court than it would have had in the state court without adding something to the cause of action.").

72 Semtek Int'l Inc. v. Lockheed Martin Corp., 531 U.S 497 (2001) (incorporating state preclusion rules) is a notable example in the Erie context.

${ }^{73}$ I think that this account is better because the idea that Guaranty Trust means that a federal court can override a state's characterization of its own law is constitutionally untenable.

${ }^{74}$ See infra Part III.A.

75 See infra Part III.C.

${ }^{76}$ See infra Part III.D.

77313 U.S. 487 (1941). 


\section{KLAXON}

\section{A. The Decision}

Erie, dealing with a railroad engaged in interstate commerce, did not provide the best facts to illustrate the thesis that general law issues lay beyond the power of the federal government. Similarly, Klaxon's facts are a poor choice to illustrate the principles for which it stands, and although I will propose altering them to facilitate analysis, it is nonetheless worth stating them briefly.

In 1918, Stentor Electric Manufacturing, a New York corporation, transferred its entire business to Klaxon Company, a Delaware corporation. ${ }^{78}$ Klaxon agreed to use its best efforts to manufacture and sell some devices for which Stentor held patents and to give Stentor a share of the profits. ${ }^{79}$ In 1929, unhappy with Klaxon's efforts, Stentor sued in the federal district court in Delaware. ${ }^{80}$ As the contract was formed in New York and performance began there, the district court applied New York substantive law. ${ }^{81}$ In 1939 , Stentor won a jury verdict for $\$ 100,000 .{ }^{82}$ It then sought to increase the judgment by adding $6 \%$ interest dating from the filing of the suit on June 1, 1929. ${ }^{83}$ Such interest was allowed under New York law, but not, as the plaintiff alleged, under the law of Delaware. ${ }^{84}$

Whose law should determine whether this interest should be allowed? From the Erie perspective, this was an issue of substantive law, so Erie answered that state law should determine it. But which state's law? Deciding between Delaware and New York required an interstate choice-oflaw decision turning on whether the availability of interest was substantive or procedural (this distinction operating now in the choice-of-law sense, rather than the Erie sense). Substantive issues in choice of law are determined by the law providing the cause of action (in this case, New York), while procedural ones are determined by the law of the forum (in this case, Delaware). In an opinion by Herbert Goodrich, the Third Circuit Court of Appeals pronounced the availability of interest to be substantive: "[I]t is clear by what we think is undoubtedly the better view of the law that the rules for ascertaining the measure of damages are not a matter of procedure at all, but are matters of substance ...." 85

What law was the court using to resolve this choice-of-law questionto decide whether the issue was substantive or procedural? It cited no state

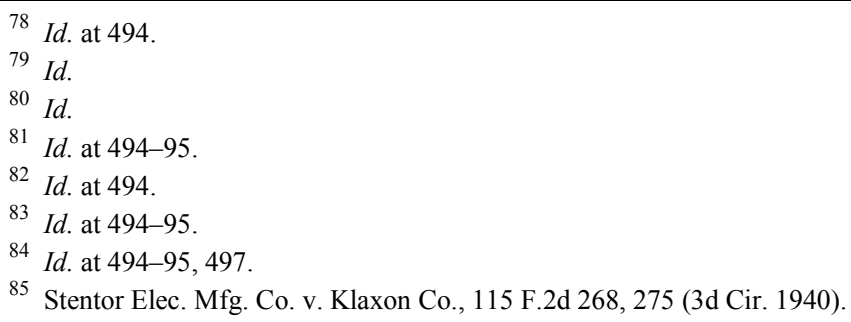


law as support for its characterization, but rather relied on the First Restatement of Conflicts and two treatises, one written by Joseph Beale (the Reporter of the First Restatement), and one by Herbert Goodrich (the author of the opinion). ${ }^{86}$ The oracular pronouncement that this was "the better view" certainly smacked of the forbidden general law. But because that no longer existed at the time of the Third Circuit's decision in 1940, it would be more charitable to read Goodrich's opinion as federal common law. This would be permissible if choice-of-law rules were procedural in the Erie sense - then federal courts would of course apply federal choice-of-law rules and state courts would apply state rules.

But, said the Supreme Court, they are not. "We are of opinion that the prohibition declared in Erie . . against such independent determinations by the federal courts, extends to the field of conflict of laws." ${ }^{87}$ In the Erie sense, choice-of-law rules are substantive and federal courts must therefore apply those of the states. The facts of Klaxon are complicated, dealing as they do with the substance-procedure characterization, but the reasoning seems fairly straightforward. Federal courts apply state substantive law in diversity actions, and choice-of-law rules are substantive; hence, federal courts must apply state choice-of-law rules.

\section{B. Assessment}

While Erie is generally celebrated in the legal academy, ${ }^{88}$ Klaxon has received a much more mixed reception. Henry Hart and others have criticized it as destructive of much of the intended benefit of diversity jurisdiction, which aimed to protect out-of-staters from unfavorable local law as well as biased courts. ${ }^{89}$ And even those who favor Klaxon do not give it as much respect as Erie. Klaxon is not constitutionally grounded, most people think; it is merely a policy-based extension of the Erie doctrine ${ }^{90}$ Erie, on this view, tells us that federal courts exercising diversity

${ }^{86} I d$. at $275-76$ ("With regard to the item of interest as damages for breach of a contract the Restatement of Conflict of Laws, $\S 418$ says: 'The rate of interest allowed as part of the damages for the breach of a contract is determined by the law of the place of performance.' See also Goodrich on Conflict of Laws (2d Ed. 1938) 215 and cases cited in note 101; 2 Beale, The Conflict of Laws (1935) 1335 and cases cited in note $6 . ")$.

${ }^{87}$ Klaxon, 313 U.S. at 496.

${ }^{88}$ See Green, supra note 1, at 595 \& n.2.

89 See Henry M. Hart, Jr., The Relations Between State and Federal Law, 54 Colum. L. Rev. 489, 513-15 (1954); Douglas Laycock, Equal Citizens of Equal and Territorial States: The Constitutional Foundations of Choice of Law, 92 CoLuM. L. REV. 249, 282 (1992); see also, e.g., Patrick J. Borchers, The Origins of Diversity Jurisdiction, the Rise of Legal Positivism, and a Brave New World for Erie and Klaxon, 72 Tex. L. Rev. 79 (1993) (critiquing Erie and Klaxon); Scott Fruehwald, Choice of Law in Federal Courts: A Reevaluation, 37 BRANDEIS L.J. 21 (1998) (criticizing Klaxon).

90 See, e.g., Stephen B. Burbank, The Class Action Fairness Act of 2005 in Historical Context: A Preliminary View, 156 U. PA. L. REV. 1439, 1502 (2008) (noting that Klaxon is "not constitutionally required"); Linda Silberman, The Role of Choice of Law in National Class Actions, 156 U. PA. L. REV. 
jurisdiction should apply the substantive law of the states in which they sit. Klaxon just takes the modest additional step of deciding that choice-of-law rules are substantive for Erie purposes, much as Guaranty Trust made that decision for limitations periods. ${ }^{91}$

I will argue that this view of Klaxon is seriously mistaken, but the analysis will prove easier to follow and likely more convincing if we consider not the facts of Klaxon itself, but a slightly different situation. This is not an attempt to tilt the field in my favor but rather to return it to level. Klaxon is a decision about the status of choice-of-law rules under Erie, but it features the esoteric and somewhat confusing example of substanceprocedure characterization. Characterization is a persistent problem in choice of law, but it is not the main focus. Instead, choice-of-law rules primarily do two things, corresponding to the two steps of the model set out earlier. First, choice-of-law rules set the scope of state law. ${ }^{92}$ They determine who can claim rights under state law-what people, where, and in what circumstances. In this function, they are what I call "rules of scope." Second, they resolve conflicts between state laws. ${ }^{93}$ They determine which of two conflicting rights under different states' laws will prevail. In this function, they are what I call "rules of priority."

Let us suppose, then, that rather than a substance-procedure characterization, we are dealing with the more usual issues of scope and priority. Suppose that a married couple from Iowa drives into Kansas and gets into an accident there, for which the wife sues the husband. As far as substantive law goes, suppose that Iowa follows the doctrine of interspousal tort immunity: Iowa does not allow spouses to sue each other. Kansas does not follow the doctrine, so spouses may sue each other under its law. As far as choice of law goes, Kansas follows the traditional territorialist approach, deciding tort cases under the law of the place of injury, while Iowa has adopted the more modern Restatement (Second) of Conflicts, which directs courts to apply the law of the state with the "most significant relationship" to an issue in dispute. ${ }^{94}$

How will the states approach this case? They need to determine the scope of the relevant laws and their relative priority if a conflict exists. But they would do so in different ways, consistent with the different approaches to choice of law they have adopted.

The Kansas court would focus on the location of the accident. Because the accident occurred in Kansas, the territorialist approach holds, the parties' rights and liabilities must be determined in accordance with Kansas

\footnotetext{
2001, 2027 (2008) ("The Klaxon rule . . is not required either by the Constitution or by the Rules of Decision Act.").

${ }^{91}$ See supra text accompanying notes 68-69.

92 See RoOSEVELT, supra note 52.

93 Id. at 2.

94 RESTATEMENT (SECOND) OF CONFLICT OF LAWS $\S \S 145,188$ (1971).
} 
law. As far as scope goes, Kansas law attaches legal consequences and other laws do not. Because no other state's law reaches the accident, there is no need for a determination of relative priority: Kansas law governs and the wife prevails. (According to the Kansas view of things, that is, this accident presents the same kind of situation as Erie: the accident falls within the scope of only one sovereign's law.)

An Iowa court, by contrast, would not use state borders to circumscribe the scope of state law. Using the Second Restatement, it would assume that state laws have broad scope, possibly as broad as the Constitution allows. ${ }^{95}$ Kansas law grants the wife a cause of action, but Iowa law provides the husband with a defense. Finding conflicting rights, the Iowa court would proceed to a priority determination: it would ask which state has the most significant relationship to the issue of interspousal tort immunity. It would decide that this state is Iowa, as the state of the marital domicile, and it would apply Iowa law: the husband prevails. ${ }^{96}$

Analysis in Kansas Court

\begin{tabular}{c|cc|}
\hline Scope: & Only Kansas law creates rights & Both states' laws create rights \\
Priority: & $\begin{array}{c}\text { No need for priority } \\
\text { determination }\end{array}$ & Iowa law prevails \\
Outcome: & Wife wins & Husband wins
\end{tabular}

This revised fact pattern may make it easier to see how Klaxon works. Klaxon says that federal courts exercising diversity jurisdiction must apply the choice-of-law rules of the states in which they sit. ${ }^{97}$ Thus, if this case could be heard in federal court, ${ }^{98}$ a district court in Kansas would adopt territorialism and find no interspousal tort immunity defense available, while one sitting in Iowa would follow the Second Restatement and give priority to the immunity. But must the federal courts do this under constitutional compulsion, or is Klaxon based only on policy grounds?

The argument for a constitutional basis is quite simple. ${ }^{99}$ Once a federal court has decided, for whatever reason, to apply a state's law, there are limits on the extent to which it can deform that law. Suppose, for instance, that a federal court exercising diversity jurisdiction were to apply a state

\footnotetext{
${ }^{95}$ See id. $\$ 9$.

96 See id. $\S \S 6,169$.

97 See supra text accompanying note 87.

98 As I have constructed the hypothetical, diversity jurisdiction would not be available, but supplemental jurisdiction might be if we added appropriate additional facts.

99 See Roosevelt, Renvoi, supra note 6, at 1861-64.
} 
statute that required a plaintiff to show four elements of a tort to recover. Could the judge decide that in federal court only three elements would be required? Certainly not, at least if she still claimed to be applying state law. ${ }^{100}$

What if the issue were not about the required elements of the cause of action, but about the geographical scope of state law? What if the statute said that it applied to all torts "committed within this state"? There, too, the federal court could not disregard that geographical restriction and still claim to be applying state law. ${ }^{101}$ And why should the analysis change if the scope of state law is set not by statutory language, but rather by a choice-of-law approach developed by the state's high court? Statutory Erie tells us that the decisions of state courts are part of the laws of the states. ${ }^{102}$ The scope of state law is a question of its meaning, and no one now doubts that state courts have the last word on the meaning of state law. As the Supreme Court put it later in Byrd v. Blue Ridge Rural Electric Cooperative, "[F]ederal courts ... must respect the definition of state-created rights and obligations by the state courts."103

So the federal court should not be free to disregard a state's definition of the scope of its law, whether that definition is accomplished through explicit statutory language or through choice-of-law rules. ${ }^{104}$ On the facts I have set out, a federal court that decided to apply Kansas law would have to respect the territorial limits Kansas courts placed on its scope, and one applying Iowa law would have to respect the fact that the Iowa courts do not consider their law territorially limited. Doing anything else would not truly be applying state law.

Klaxon is constitutionally grounded, according to this argument, to the extent that it directs federal courts to follow state rules about the scope of their law. The argument that state choice-of-law rules are substantive in this sense- so much a part of state-created rights that a court that ignores them is not really applying the law of that state - is both straightforward and strong. We could even describe it as an application of constitutional Erie: on the issue of the scope of a state law, the state has power and the federal

100 See, e.g., Green, supra note 45, at 1167 (noting that Erie requires federal courts to follow state supreme court interpretations of state law).

${ }^{101} I d$. The rule that the Supreme Court has announced here is that federal courts must apply state law as the state courts have interpreted it, so I am assuming that state courts applied the statutes as written-limiting the geographical scope in this example, and requiring four elements of the tort in the prior example.

102 See Erie R.R. v. Tompkins, 304 U.S. 64, 72, 79 (1938).

103356 U.S. 525, 535 (1958).

104 Interestingly, the Supreme Court has accepted this point in the context of the Federal Tort Claims Act (FTCA). See Richards v. United States, 369 U.S. 1, 10-13 (1962) (interpreting reference to state "law" in FTCA to include choice-of-law rules). 
government does not; ${ }^{105}$ therefore, state and not federal law must be consulted to determine scope.

So a Kansas court, to return to my modified Klaxon fact pattern, would be entitled to say that Kansas tort law gave rights to all persons and only persons injured within the state, and a federal court - whether sitting in Kansas or not - would have to respect that definition. The Iowa court would be entitled to decide the scope of Iowa law and federal courts would likewise have to respect that definition. ${ }^{106}$

That is the analysis with respect to the scope of state law. Matters of priority are different. States are entitled to decide, within constitutional limits, who can claim rights under their laws and who cannot - that is a question of the meaning of their laws. But obviously no one state can have the last word on the question of whose rights will prevail in case of a conflict. State rules of priority are not binding, either on federal courts or the courts of sister states, because whether a right created by one state's law should prevail over a right created by another is not a matter within the authority of any single state - it is not a question of the meaning of state law. ${ }^{107}$ The question of priority is therefore a question on which federal courts should be independent, though for policy reasons - policy Erie, in fact - it will usually be desirable to maintain intrastate uniformity by following the rules of priority of the state in which they sit. When a state is unreasonably aggressive in its rule of priority, however-when it privileges local law over foreign law to an unreasonable degree ${ }^{108}$ - a federal court is free to resolve the conflict differently.

As I would analyze my modified Klaxon fact pattern, all federal courts would be required to recognize that a conflict exists between Kansas law

105 The federal government has the power to preempt state law, of course, but a federal court exercising diversity jurisdiction does not purport to be exercising that power.

${ }^{106}$ Later I will argue that state courts must also defer to sister states on the scope of their law. See infra Part III.A.

107 Such issues are not disputes between states as parties, and therefore there is no need for a federal-law solution that binds both. But they otherwise fit the description of interstate disputes that cannot be controlled by state law. See, e.g., Bradford R. Clark, Federal Common Law: A Structural Reinterpretation, 144 U. PA. L. REV. 1245, 1325 (1996) ("Because states are coequal sovereigns under the Constitution, neither party to an interstate dispute has legislative power to prescribe rules of decision binding upon the other." (footnote omitted)).

108 Adoption of state law while reserving a veto power to protect federal interests is relatively common. See Roosevelt, supra note 20, at 1904-05 (describing the practice). And it should also be clear that an unreasonable disregard of foreign law undermines the federal interest in diversity jurisdiction: providing a level playing field for litigants. See Allan Erbsen, Horizontal Federalism, 93 MINN. L. ReV. 493, 537-43, 558-59 nn.234, 236 (2008). The harder question is what counts as unreasonable. I would expect the reserved federal veto to be invoked in only a very few situations, perhaps only two: first, when a state court used its own limitations period to extend an action despite having no contacts with the underlying events, see Sun Oil Co. v. Wortman, 486 U.S. 717, 722 (1988), and second, when it relied on "public policy" to sever a limit on a foreign cause of action, see Kilberg v. Ne. Airlines, Inc., 172 N.E.2d 526, 527-28 (N.Y. 1961). 
and Iowa law. That is a question of scope. Each state says, through its choice-of-law rules, that its law reaches the case, and those determinations must be respected. At the priority stage, each state says that its law prevails-Kansas because it gives priority to the territorially appropriate law, and Iowa because it believes the state of marital domicile has the most significant relationship. Neither state court can bind the other on this question, and neither can bind a federal court, though for policy reasons a federal court in Kansas should probably follow the Kansas rule, and likewise for one in Iowa. ${ }^{109}$

\section{Recapitulation}

The next Part of this Article will discuss the implications of the twostep view of Erie and Klaxon for various doctrinal and theoretical puzzles. But first, it may be worth attempting a brief summary for the sake of clarity. What I have argued thus far is the following:

The significant move in Erie is its denial of the existence of the general law. Once that proposition is accepted, everything else follows in quite straightforward fashion. On its facts, Erie is basically a choice-of-law decision holding that if only one law reaches the facts-if only one sovereign has attempted to (or has power to) regulate the relevant transaction or occurrence- then that law must supply the rule of decision.

Erie also has a policy basis, which is the desire to preserve uniformity between state and federal courts within a single state. This policy should guide analysis in resolving choice-of-law problems between state substantive law and federal procedure - it should help us decide when overlapping federal procedure preempts state substance. And it should help us decide when federal law should incorporate state law, which is what

\footnotetext{
109 One might well ask why federal courts should be merely independent, rather than authoritative. If a federal court makes a rule of priority, why is that not federal common law that preempts inconsistent state law? If the federal court were making rules of priority pursuant to a direction from Congress, or if Congress legislated, I believe the federal rules of priority would be preemptive. For a discussion of such legislation, see Michael H. Gottesman, Draining the Dismal Swamp: The Case for Federal Choice of Law Statutes, 80 GEO. L.J. 1 (1991). Uniform federal rules of priority, promulgated under Congress's Full Faith and Credit Clause power, would actually be a nice thing to have. In the absence of congressional action, however, the federal lawmaking is based only on necessity: no state has the power to answer the priority question authoritatively, so federal courts must be independent. See Hinderlider v. La Plata River \& Cherry Creek Ditch Co., 304 U.S. 92, 110 (1938) (noting that question of rival state claims to water was one "upon which neither the statutes nor the decisions of either State can be conclusive"). If states lacked power to answer the priority question at all, then this necessity-born federal law would also supply the rule of decision in state court, as it did in Hinderlider. Id. at 107. But given the traditional practice of allowing states wide latitude to decide the issue of priority under their own law in their own courts, see Allstate Ins. Co. v. Hague, 449 U.S. 302, 307-08 (1981), giving the federal rule of priority preemptive force seems a step too far. Alternatively, if this federal common law were to have preemptive force, it could still work by incorporating the preexisting state rule as the Court did in Semtek. Semtek Int'l Inc. v. Lockheed Martin Corp., 531 U.S. 497, 506-09 (2001) (incorporating state preclusion rules to determine effect of federal court diversity judgments).
} 
happens when a state procedural law is characterized as substantive for Erie purposes. ${ }^{110}$

Klaxon makes obvious sense given the policy aims of Erie. But it also has a constitutional source in that once a federal court decides to apply the law of a state, it is not free to alter the content of that law. It must respect the state definition of rights and obligations, and choice-of-law rules about the scope of state law are part of that definition. States have the power to set the scope of their laws; federal courts do not.

Rules of priority are different. The relative priority of two states' laws is a question on which no single state can be authoritative. Federal courts are independent of state law on issues of priority. For policy reasons, they will usually incorporate the rules of priority of the states in which they sit, but they reserve a "federal veto"- the power to diverge from a state rule of priority that unreasonably disfavors foreign law.

\section{APPLICATIONS}

Thus far, I have argued for an understanding of Erie and Klaxon that is informed by a choice-of-law perspective. That is, it attempts to view the cases within the analytical framework that I have elsewhere suggested is appropriate for choice of law ${ }^{111}$ : the two-step model that allocates authority among sovereigns by first considering the scope of their laws and then by using rules of priority to resolve conflicts. Erie is relatively trivial from this perspective once the general law is disposed of: because only one sovereign has exercised lawmaking power, that sovereign's law obviously must supply the rules of decision.

Klaxon appears a little different, and here my analysis departs substantially from the standard account. I think that my analysis of Klaxon is better than the standard view because it reconciles the decision with Erie's constitutional principles - it shows how state authority over the scope of state law is, like Erie, a situation in which only one sovereign has exercised its regulatory power. It also explains how the "neutral umpire" benefits of diversity jurisdiction might be retained without overruling Klaxon entirely-if federal courts follow states as to the scope of their law while retaining independence on priority questions. ${ }^{12}$ But I also want to argue that the two-step model is superior to the standard account because it helps us resolve some otherwise intractable problems. This Part of the Article thus examines a selection of Erie-Klaxon problems that have proven difficult or notorious.

\footnotetext{
110 See Guaranty Trust Co. v. York, 326 U.S. 99, 109 (1945).

111 See, e.g., ROOSEVELT, supra note 52.

112 See infra text accompanying notes $147-55$.
} 


\section{A. Erie and Klaxon in State Courts}

What could Erie and Klaxon mean for state courts? Nothing, is the ordinary view. Erie is about the scope of federal authority and the duties of federal courts when federal lawmaking power does not exist or has not been exercised. It has no implications for state courts. So goes the conventional wisdom. ${ }^{113}$

But that response is much too quick. The constitutional principle that I drew from Erie is a basic premise about the allocation of authority between sovereigns, and it applies just as well to interstate relations as to statefederal ones. Erie's facts present a situation where federal lawmaking power does not exist or has not been exercised, with the consequence that state law must supply the rule of decision. Surely this has an interstate analogue: if the forum state lacks or has not exercised lawmaking authority, some other state's law must supply the rule of decision.

Again, the conventional wisdom would probably be to reject this argument. Erie depended on the fact that Congress lacks a general police power, one might say, and state legislatures have that power. There are no topics beyond their authority in the way that the "general law" questions of everyday tort and contract were outside congressional power in Erie.

But this response is demonstrably wrong, even speaking solely in terms of our current caselaw. There are topics beyond the lawmaking power of the states, and the Supreme Court has said so. One such topic is the rights and obligations arising from events that have no connection to the forum state. As Michael Green puts it, "Like a federal court, a state court does not have lawmaking power simply because it has jurisdiction over a case. The transaction being litigated can be subject to the exclusive lawmaking power of a sister state." 114 In such cases, the Supreme Court has explained, the Constitution forbids the forum state from using its own law as a rule of decision. ${ }^{115}$ Following Green, I will call the duty to use sister-state law "horizontal Erie."

But horizontal-Erie obligations do not arise only when the entire transaction is outside the forum's lawmaking authority. ${ }^{116}$ They can also exist as to particular issues, even when other issues do fall within it. (This is why, in the vertical context, federal courts have to follow Erie when exercising supplemental jurisdiction ${ }^{117}$ : the fact that federal law governs one issue in a case does not necessarily mean that federal lawmaking authority

113 See Michael Steven Green, Horizontal Erie and the Presumption of Forum Law, 109 MiCH. L. REV. 1237, 1239 (2011) (noting the little attention paid to this issue).

114 Id. at 1240.

115 See Allstate Ins. Co. v. Hague, 449 U.S. 302, 308 (1981).

116 See Green, supra note 113, at 1247.

117 See United Mine Workers v. Gibbs, 383 U.S. 715, 726 (1966). 
reaches every issue.) So what is an issue beyond the lawmaking authority of one state?

How about the content of sister-state law? That each state has exclusive authority over the meaning and scope of its law, subject to constitutional limits or federal preemption, should seem fairly obvious. It follows from constitutional Erie, because states simply lack power to make other states' laws. ${ }^{118}$ Authority over the question of who can claim rights under New York law is given to the courts and legislature of New York and withheld from other states, just as clearly as authority over everyday torts and contracts was given to the states and withheld from the federal government in Erie. The principle also follows from Erie's assertions about the authority of state courts that the laws of the states are what their courts say they are, not what someone else might think is desirable. ${ }^{119}$ Indeed, the Supreme Court has recognized this principle, deriving it from the Full Faith and Credit Clause. ${ }^{120}$ The conclusion that follows is that state courts are constitutionally bound to respect sister-state choice-of-law rules to the extent that they define the scope of state law. To the extent this conclusion is not honored - to the extent that one state asserts the authority to define the scope of another's law-our choice-of-law system continues the error of Swift v. Tyson.

Perhaps surprisingly, choice of law is still waiting for its Erie. The Supreme Court has never said that states' rules about the scope of their law are binding - not when they take the form of choice-of-law rules ${ }^{121}$ - and state courts regularly ignore sister-state choice-of-law rules. No one can say with confidence why this is so, but I have some guesses. First, much like the federal courts during the Swift era, the state courts engaging in this practice likely do not realize they are violating the principle of Erie. Swiftera federal courts, remember, did not think that they were independent of state courts on certain questions of state law; they thought that the general law was not state law. Just so, state courts today presumably do not think they are independent authorities on the meaning of sister-state law, at least not if it is clearly established and brought to their attention. ${ }^{122}$ They simply

118 Because of the complete lack of lawmaking power, the constitutional argument for this application of horizontal Erie is actually stronger than the constitutional argument for Klaxon, where Congress has power over choice of law but has not exercised it.

119 See Erie R.R. v. Tompkins, 304 U.S. 64, 79 (1938).

${ }^{120}$ See Sun Oil Co. v. Wortman, 486 U.S. 717, 730-31 (1988); see also Shady Grove Orthopedic Assocs., P.A. v. Allstate Ins. Co., 130 S. Ct. 1431, 1443 (2010) (plurality opinion) ("New York has no power to alter substantive rights and duties created by other sovereigns.").

${ }^{121}$ If they take the form of statutory specifications, by contrast, sister-state disregard violates the Full Faith and Credit Clause.

122 See Wortman, 486 U.S. at 730-31. 
do not think of choice-of-law analysis in terms of scope and priority; rather, they most likely understand it as some sort of metaprocedure. ${ }^{123}$

I have argued that this understanding is unsound, but its appeal is understandable given that the alternative seems impossible. The second factor at work is that if we do suppose that a state's choice-of-law rules are part of its law-so that we must apply them whenever we apply that state's law-we run into all the problems choice of law puts under the name of renvoi. ${ }^{124}$ In particular, if two states' choice-of-law rules each point to the other, it seems simply impossible to decide the case.

However, this perception is a result of failing to use the two-step model. Once we separate choice of law into the two issues of scope and priority, it becomes clear that a system whereby each state is authoritative with respect to the scope of its own law but not with respect to that law's relative priority is indeed possible.

Changing the facts of the earlier hypothetical will allow us to see this. Suppose, as we did in the discussion of Klaxon, that Kansas follows a territorial approach to choice of law while Iowa has adopted the Second Restatement. But reverse the facts by supposing that a married couple from Kansas gets into an accident in Iowa. Now the Kansas choice-of-law ruleterritoriality - points to Iowa law on the issue of interspousal tort immunity. But the Iowa choice-of-law rule-most significant relationship - points to the law of shared domicile, Kansas. If we say that states are obliged to heed each other's choice-of-law rules, we seem to have created the dread infinite cycle; an endless ping-pong back and forth.

But we have not. The first step of the two-step model is to think about the scope of the states' laws. Kansas has decided that its law is territorial. Well and good for Kansas; its law creates no rights related to an accident in Iowa. What about Iowa's law? To determine the scope of Iowa law, we look to the Iowa court. Iowa, following the Second Restatement, gives its law maximum scope, so it does create rights related to this accident. Scope analysis handles this hypothetical by itself, just as it does Erie: the case must be decided under Iowa law because that is the only law that reaches the facts, and there is thus no need for a priority determination.

Why did the scope analysis avoid the paradox that conventional choice-of-law thinking generated? Because a state following the

123 This view is pretty clearly mistaken, I have suggested, because choice-of-law rules do obviously set the scope of state law in just the same way as explicit statutory limits. See supra text accompanying notes 99-104. The Supreme Court, interpreting a federal statute, has also stated that a state's choice-oflaw rules are part of its "law" and must be consulted to determine what rights that law gives. See Richards v. United States, 369 U.S. 1, 11 (1962); see also Larry Kramer, Choice of Law in Complex Litigation, 71 N.Y.U. L. REV. 547, 568-70 (1996) (arguing that choice-of-law rules are substantive).

${ }^{124}$ Literally, "renvoi" means a sending-back or remission. Kramer, supra note 55, at 979-80. In choice of law, it is used to refer generally to the question of what effect one state should give to the choice-of-law rules of another. 
conventional thinking will use its choice-of-law approach not only to determine the scope of its own law (which is within its power) but also to determine the scope of other states' laws (which is not). What happened in the conventional choice-of-law analysis above was that Iowa mistakenly deemed Kansas law to be as expansive as its own. ${ }^{125}$ That is what allowed Iowa to conclude that Kansas law should be applied in preference to Iowa law even though, according to Kansas courts, Kansas law does not reach the facts of the case.

Accepting that a state's choice-of-law rules are in part about the scope of its law, and hence in part subject to the exclusive authority of that state, would be a relatively significant conceptual change in the conventional approach to choice of law. ${ }^{126}$ Its practical consequences, however, would be ones that the modern approaches have been moving toward. The Second Restatement, though still puzzled by renvoi, has recognized that another state's choice-of-law rules can provide useful information about whether that state seeks to regulate a transaction. ${ }^{127} \mathrm{My}$ analysis narrows this point to the question of scope and sharpens it to a constitutional command, but the import is much the same.

The change that would come from accepting the two-step model, in fact, would be exactly the same kind as that worked by Erie: once we realize that a particular legal question (the scope of state law) is within the authority of that state and no one else, the independence that other courts have asserted on that question looks like an unconstitutional usurpation of authority. But just as Erie had policy support in addition to its constitutional grounds, this suggestion does too. On questions of scope, it will produce uniformity not just within a state (i.e., in state and federal courts) but among different states. It will also, as suggested above, eliminate the vexing problem of renvoi, which simply never arises in the two-step analysis.

\section{B. Van Dusen, Ferens, and Characterization}

One of the most notorious oddities of choice of law is the situation that results when a case filed under the diversity jurisdiction of a federal court in one state is transferred to a district court in another state pursuant to 28 U.S.C. $\S 1404\left(\right.$ a). ${ }^{128}$ How should the principles of Erie and Klaxon apply

125 Kansas also mistakenly deemed Iowa law territorial, but this error was of no real consequence.

126 See Roosevelt, Renvoi, supra note 6, at 1887-90.

127 See Restatement (SECOND) OF CONFLiCT OF LAws $\S 8 \mathrm{cmt}$. k (1971).

128 Section 1404(a) allows federal district courts to transfer cases to another district in which they might have been brought "[f]or the convenience of parties and witnesses, in the interest of justice." 28 U.S.C. § 1404(a) (2006). 
here? In two cases, the Supreme Court articulated an approach that has left commentators scratching their heads. ${ }^{129}$

In Van Dusen v. Barrack, the Court decided that a defendant's transfer under $\S 1404(a)$ should produce "but a change of courtrooms," and not a change of law. ${ }^{130}$ For a case filed in federal district court in Pennsylvania and then transferred to the district of Massachusetts at the defendant's request (the situation in Van Dusen), the Supreme Court stated that the federal court in Massachusetts should apply the same law that the court in Pennsylvania would have applied - namely, Pennsylvania choice-of-law rules and whatever substantive law they selected. As the Court put it, "[T] he critical identity to be maintained is between the federal district court which decides the case and the courts of the State in which the action was filed." 131

Thus far, the result may seem reasonable enough. Under Erie, the federal court in Massachusetts would have to try to achieve substantial uniformity with the courts of some state, and sticking to the state where the action was initially filed makes a fair amount of sense. Most obviously, it protects the plaintiff's choice of law, if not forum, by preventing the defendant from using $\S 1404$ (a) to change the rules as well as the playing field.

Twenty-six years later, however, an odder consequence emerged. In Ferens v. John Deere Co., the plaintiff, a Pennsylvania resident, was injured in Pennsylvania by a combine manufactured by a Delaware corporation. ${ }^{132}$ Clearly, this gave him a tort claim under Pennsylvania law, but that law also provided a two-year limitations period for torts, and Ferens did not file his suit until three years after the accident. ${ }^{133}$ In Pennsylvania state court his tort claim would have been untimely, and a federal court in Pennsylvania would also have applied the Pennsylvania limitations period and dismissed because limitations periods are substantive for Erie purposes.

So Ferens brought his Pennsylvania tort claims in federal court in Mississippi, where the limitations period was six years. ${ }^{134}$ Crucially, the limitations period was considered procedural for choice-of-law purposes by the Mississippi courts, meaning that a Mississippi state court would apply the Mississippi limit and not the Pennsylvania limit, even though

129 See, e.g., Geoffrey C. Hazard, Jr., Has the Erie Doctrine Been Repealed by Congress?, 156 U. PA. L. REV. 1629, 1635 (2008) (stating that Ferens v. John Deere Co., 494 U.S. 516 (1990), is a "bizarre result" with a "surreal quality").

130376 U.S. 612, 639 (1964).

${ }^{131} \mathrm{Id}$.

132494 U.S. 516, 519 (1990). His wife also sued, see id., but for simplicity I will refer to the plaintiff as Ferens in the singular.

${ }^{133}$ Id.

${ }^{134}$ Id. at 519-20. 
Pennsylvania law provided the underlying substantive rights. ${ }^{135}$ Following Klaxon, the federal district court in Mississippi applied the same choice-oflaw analysis a Mississippi court would and dutifully deemed the tort claim timely. Thereupon the plaintiff moved to transfer the case under $\S 1404(\mathrm{a})$ and the proceedings moved to the Western District of Pennsylvania. ${ }^{136}$

Van Dusen made clear that a defendant who moved for a transfer could obtain a change of venue but not a change of law. Not so for plaintiffs, said the district court in Ferens. Without "some measure of good faith expectation of proceeding in the court in which the complaint is filed" the filing in Mississippi was "merely a procedural ploy" that should not allow Ferens to pick up the longer limitations period en route to Pennsylvania. ${ }^{137}$ The Third Circuit affirmed, initially on the alternate ground that application of the Mississippi limitations period would violate the Constitution, but ultimately on the same theory. ${ }^{138}$

The Supreme Court reversed. ${ }^{139}$ The five-Justice majority said that denying Ferens the ability to rely on the Mississippi limitations period would simply encourage him to continue to litigate in Mississippi, which was obviously a less convenient forum. ${ }^{140}$ True, he had sought out that forum, and allowing him to take its limitations period with him to Pennsylvania rewarded his procedural manipulations. But the burden of litigating in Mississippi did not fall on the plaintiff alone, and "[t]he desire to take a punitive view of the plaintiff's actions should not obscure the systemic costs of litigating in an inconvenient place."141

It may be true, as the Court suggested, that the systemic costs of a different rule would be greater if plaintiffs simply litigated entire cases in inconvenient forums in order to preserve favorable law. All the same, the result in Ferens is surprising. We are used to the idea that plaintiffs go to a forum in order to get its law, but we are less used to the idea that they can order it for takeout. The end result — that Ferens can litigate in Pennsylvania

135 Id

136 Id. at 520

137 Ferens v. Deere \& Co., 639 F. Supp. 1484, 1491 (W.D. Pa. 1986).

138 The first Third Circuit decision, Ferens v. Deere \& Co., 819 F.2d 423 (3d Cir. 1987), was vacated and remanded by the Supreme Court, Ferens v. Deere \& Co., 487 U.S. 1212, 1212-13 (1988) (mem.), in light of Sun Oil Co. v. Wortman, 486 U.S. 717 (1988), which held that a state with no connection to underlying litigation could nonetheless apply its own procedural rules, including limitations periods. Sun Oil Co., 486 U.S. at 722. On remand, the Third Circuit focused on the forumshopping issue and held that Pennsylvania law should control the issue of timeliness. Ferens v. Deere $\&$ Co., 862 F.2d. 31, 35-36 (3d Cir. 1988).

139 Ferens, 494 U.S. at 533.

140 Id. at 531.

141 Id. at 530. But see id. at 537 (Scalia, J., dissenting) (suggesting that these costs could be reduced by district judges transferring cases sua sponte, and that the Van Dusen rule need not apply to such transfers). 
while retaining a limitations period plucked from Mississippi law-seems quite inconsistent with the policy-Erie goal of substantial uniformity. ${ }^{142}$

Admittedly, this oddity is not due entirely to the Court's rule. If Mississippi characterized limitations periods as substantive, or if it required plaintiffs relying on claims under foreign law to meet the corresponding foreign limitations period, as most states do, ${ }^{143}$ Ferens's procedural ploy would not have worked. Still, the outcome is strange enough that it might be worth asking whether we can do better. Apart from adopting the dissent and saying that plaintiff-initiated transfers should get transferee law, is there another way of looking at the case?

Again, I think that viewing the matter from the two-step perspective will help. The first step is to determine the scope of state law, to ask which states' laws create rights. Pennsylvania law gives Ferens a tort claim, but it also gives Deere a defense: the two-year limitations period. Mississippi also gives Ferens a right. Because its limitations period runs for six years, it gives him a right to sue until that time has elapsed.

Does the Mississippi right to sue conflict with the Pennsylvania defense? Not necessarily. It might be the case that these rights are good only in certain courts. Unambiguously procedural rights, like the right to use a certain number of pages in a brief or to take a certain number of days to file a response, are plainly intended only to apply in the courts of the forum. ${ }^{144}$ Pennsylvania law might allow Ferens fifty pages, and Mississippi law only forty, but there is no conflict between them. He has the right to fifty pages in a Pennsylvania court and forty in a Mississippi court, and neither state intends to confer a right in the courts of the other.

With respect to limitations periods, however, there probably is a conflict. The purpose of the Pennsylvania two-year limit is presumably in part to regulate Pennsylvania courts. From this perspective, it is intended to allocate Pennsylvania judicial resources to the litigation of fresh rather than stale claims, and it reflects an assessment of how quickly tort claims can and should be brought. ${ }^{145}$ If that were the only purpose, we would not expect defendants to be able to raise it in the courts of other states. But it is also presumably intended to give defendants peace of mind after it has elapsed-it is intended to shield them from liability. This defendant-

${ }^{142}$ In dissent, Justice Scalia said the file-and-transfer stratagem "reduced to a laughingstock" the Erie-Klaxon policy. Id. at 536; see also Elizabeth T. Lear, Congress, the Federal Courts, and Forum Non Conveniens: Friction on the Frontier of the Inherent Power, 91 IowA L. REV. 1147, 1188-89 (2006) (arguing that the slippery slope of Van Dusen and its progeny, including Ferens, "leaves one nearly breathless").

143 See, e.g., Caleb Nelson, The Persistence of General Law, 106 COLUM. L. REv. 503, 550 (2006).

144 See supra text accompanying notes 63-64.

145 It presumably reflects an assessment of how quickly such claims go stale given the usual methods of proof, how important they are compared to the other claims competing for judicial attention, how much time plaintiffs need to prepare before filing, and other similar considerations. 
protective purpose is at stake no matter where litigation takes place, so it is reasonable to suppose that Pennsylvania grants this defense to Deere even in a Mississippi court.

Does Mississippi mean to give Ferens a right to sue in its courts? It is hard to see what purpose doing so would serve. Mississippi has no obvious procedural interest in holding its courts open to foreign litigants longer than the courts of foreign states - this seems to consume judicial resources for no gain. ${ }^{146}$ And it has no obvious interest as far as the parties are concerned, either-Ferens was not a Mississippi resident, and nothing related to the suit happened in Mississippi. But the Mississippi courts had decided that their limitations period was intended to govern actions like this. The scope of state law, Erie tells us, is what state courts say it is, not what someone else would think is wise. ${ }^{147}$ So Mississippi law does give Ferens a right, and it conflicts with Deere's defense under Pennsylvania law.

Because there is a conflict between rights, we have to move to the second step: deciding which state's law will get priority. Here, the arguments for Pennsylvania law seem quite strong. Pennsylvania law creates the cause of action; surely Pennsylvania should be entitled to determine when that cause of action ceases to exist, especially given that neither party is from Mississippi and the accident occurred in Pennsylvania. But Mississippi has decided that its limitation period should prevail, so that will be the result in a Mississippi court.

Why is that? The forum interest in following its own rules of procedure on questions such as the page limit for briefs is obvious: it is convenient for the court to use a single uniform set of procedural rules to govern all litigation, and the particular rules the state has chosen for its courts reflect its views on, for instance, how many pages parties should be given to make their case. But this kind of interest does not exist in Ferens-there is no

146 Conceivably, Mississippi could aspire to become a magnet for litigation, which might serve the interest of the plaintiffs' bar. But it seems more likely that it simply adhered without much thought to the traditional choice-of-law characterization of limitations periods as procedural.

147 There are, of course, constitutional limits on the scope of state law, and one could argue that they were exceeded in Ferens. If Mississippi claimed to be providing a cause of action under its own tort law, the response would be that it was constitutionally impermissible because Mississippi lacks sufficient contacts with the case. In Ragan v. Merchants Transfer \& Warehouse Co., the Supreme Court observed, "We cannot give [a cause of action] longer life in the federal court than it would have had in the state court without adding something to the cause of action. We may not do that consistently with Erie R. Co. v. Tompkins." 337 U.S. 530, 533-34 (1949). Why does Mississippi have the power to add to the Pennsylvania cause of action?

The answer, such as it is, is that the Supreme Court has said it can. In Sun Oil Co. v. Wortman, 486 U.S. 717 (1988), the Court held that a forum may apply its own longer limitations period to a claim based on foreign law, even when it has no contacts with the underlying litigation, if the forum deems limitations periods procedural. Id. at 728-29. One might, however, argue that a limitations period is substantive in the Byrd sense - that it is part of the state-created definition of the right. In that instance, an unrelated forum should not have the power to sever it from the foreign cause of action, or to provide that a conflicting longer forum limitations period prevails. Sun Oil does not address this argument. 
interest of Mississippi courts that is served by hearing a case that could not be brought in Pennsylvania. ${ }^{148}$

In fact, the Mississippi courts offer no reason-it is simply that they characterize the limitations period as procedural and therefore governed by forum law. ${ }^{149}$ So one thing the two-step perspective reveals is that this determination of priority is what is actually at stake in a substanceprocedure characterization, at least sometimes. Calling something procedural in a choice-of-law analysis is shorthand for the determination that it should be controlled by forum law rather than the foreign law that creates the cause of action. ${ }^{150}$ This determination may be relatively uncontroversial - if the forum and the foreign state agree that the issue is procedural, as they do for page limits, then only forum law purports to apply and, as in Erie, only one state's law reaches the facts. No question of priority arises. But if the forum deems an issue procedural while the foreign law considers it substantive, there is a conflict between the two laws, each of which is intended to apply. The forum may be entitled to decide the issue under its own law, but we should not lose sight of the fact that it has done so by giving priority to forum law and subordinating foreign law. ${ }^{151}$

So Mississippi has made a decision to give its law priority over Pennsylvania's law. It is an odd decision, based apparently more on traditional line drawing than any sensible assessment of state interests, but it is one the Supreme Court has said is constitutionally permissible. In a Mississippi state court, Ferens will not be time-barred. Must a federal court in Mississippi reproduce this odd result, with the further consequence that Ferens can transfer the case to Pennsylvania and bring the Mississippi limitations period with him?

I think the answer is no. Mississippi has made a decision to give its law priority over Pennsylvania's; this is the point that the two-step perspective on substance and procedure revealed. But according to the reading of Klaxon set forth above, there is no constitutional requirement for a federal court to follow a state's rules of priority. Nor are the policy-Erie considerations particularly weighty.

Policy Erie has two basic concerns: forum shopping and, as a consequence, arbitrary discrimination. The forum-shopping concern is that the availability of a different result in federal court will lead parties to

\footnotetext{
148 By contrast, dismissing a case that could be brought in Pennsylvania might serve an interest of Mississippi courts - that of allocating judicial resources to fresh rather than stale claims.

149 See, e.g., Williams v. Taylor Machinery, Inc., 529 So. 2d 606, 609 (Miss. 1988) ("Mississippi has always considered statutes of limitation procedural ....").

${ }^{150}$ It also suggests that the rights created should be limited to the forum's courts.

151 One way of seeing this is to consider the interaction between state and federal law, where the Supremacy Clause forbids states from giving their law priority. In obedience to that clause, states consistently use federal limitations periods for federal rights. See Kevin M. Clermont, Reverse-Erie, 82 Notre Dame L. REV. 1,30 \& n.137 (2006).
} 
choose that forum, and choosing a forum for strategic reasons is generally considered undesirable. ${ }^{152}$ The broader concern about arbitrariness is that the availability of the federal forum because of diversity will arbitrarily favor parties who want the federal outcome, while similarly situated litigants in cases where diversity does not exist cannot obtain it.

First, as to cases like Ferens itself, forum shopping is probably not undesirable. Suppose that the federal court adopts a different rule of priority and decides that on these facts the Pennsylvania defense should prevail. Deere can remove to federal court if sued in Mississippi state court, and it will win on limitations grounds. But that is not a problem, because the result in federal court is not simply different; it is better: the reason the federal court has adopted a different rule of priority is that Mississippi is unreasonably discriminating against foreign law. Protecting individuals from that kind of discrimination is one of the purposes of diversity jurisdiction. ${ }^{153}$

Second, the more general problem of arbitrariness does not exist in the same way it did under the Swift regime. Arbitrariness existed under Swift because the federal forum (and hence the federal view of the general law) was available on a basis (diversity of citizenship) that had nothing to do with whether the federal or state view should control. The federal version of the general law was available not only in multistate cases where the state forum was disrespecting foreign law, but in all cases, even a purely intrastate tort (as in Erie), as long as the parties were diverse.

In Ferens, however - as in any case in which the federal veto over state rules of priority would be invoked - the foreign citizenship is quite relevant. A federal court departing from the Mississippi rule and giving priority to Pennsylvania law would be doing so because Pennsylvania's connections with the case are so much stronger than Mississippi's that Mississippi's assertion of priority is unreasonable. This approach would sacrifice some uniformity: the federal rule of priority would not be available in a suit between two Mississippi residents with respect to a Pennsylvania tort because that suit would not generate federal diversity jurisdiction. But that suit would also look quite different in terms of the reasonableness of Mississippi's claim of priority. That claim would not be unreasonable because Mississippi would be the state of both parties' domicile and so the different outcome would not be a troubling disuniformity. ${ }^{154}$

\footnotetext{
${ }^{152}$ For a more detailed analysis of forum shopping, see Larry Kramer, Rethinking Choice of Law, 90 Colum. L. REV. 277, 313-14 (1990).

153 See Laycock, supra note 89.

154 The federal forum would also not be available in a suit between two Pennsylvania residents about a Pennsylvania tort, and the disuniformity between that suit and one of a Pennsylvania citizen versus a Delaware citizen (such as Ferens) is more troubling. But a Mississippi court in the Pennsylvanian-versus-Pennsylvanian case would most likely dismiss on forum non conveniens grounds.
} 
What does all of this mean? The problem in Ferens, as I intimated earlier, is not really that a plaintiff-initiated transfer under §1404(a) preserves the law obtained by the initial choice of forum. It is more that Mississippi, by characterizing limitations periods as procedural, claims priority for its longer period as against shorter periods under foreign law, even when foreign law creates the underlying rights. The two-step model shows us that this priority determination is really at stake in substanceprocedure characterization; it gives us a clearer understanding of the problem.

It also shows us the solution, through its interpretation of Klaxon. A federal court that follows state rules of scope but departs from unreasonable rules of priority can correct unreasonable discrimination against foreign law. That is a more appropriate outcome than for it to "play the rule [sic] of ventriloquist's dummy" to the Mississippi state courts. ${ }^{155}$

\section{Erie's Progeny: Why the Source of Federal Law Matters}

The two-step model gives us both a deeper understanding of what is troubling about the Ferens result and a way to avoid it. The real problem is Mississippi's unreasonable assertion of priority for its limitations period, and an independent federal determination of priority provides an appropriately limited cure. Additionally, its perspective on substanceprocedure characterization is of use in other cases. I argued above that when this characterization is at issue under state law, federal courts should understand that characterizing an issue as procedural amounts to placing it within the scope of forum law and giving that law priority, a decision that may not always be reasonable and can be disregarded in appropriate cases. But what about when we are dealing not with choice-of-law characterization, but instead with Erie analysis? Here, too, I will argue, seeing the substance-procedure characterization in terms of scope and priority will clarify matters.

Erie's progeny start out conceptualizing the issue in terms of an abstract dichotomy between substance and procedure. ${ }^{156}$ But they quickly abandon formalistic line drawing of the sort used by the Mississippi courts in Ferens in favor of a more practical approach. ${ }^{157}$ In Guaranty Trust, the Court adopted what has been called the outcome-determinativeness test: in order to promote policy Erie, it decided, it would class as substantive any rule that might "determine the outcome of a litigation."158

\footnotetext{
155 Richardson v. Comm'r of Internal Revenue, 126 F.2d 562, 567 (2d Cir. 1942).

156 See Sibbach v. Wilson \& Co., 312 U.S. 1, 14 (1941) ("The test must be whether a rule really regulates procedure,- - the judicial process for enforcing rights and duties recognized by substantive law and for justly administering remedy and redress for disregard or infraction of them.").

157 The idea that a sharp and meaningful line separates these two categories of law is now generally rejected. For a discussion of the relation of the two, see Main, supra note 66, at 812-18.

158326 U.S. 99, 109 (1945).
} 
But even drawing a substance-procedure line in terms of outcomedeterminativeness will not resolve all the Erie problems-not unless outcome-determinativeness marks the outer limit of federal procedural lawmaking power, which it does not. ${ }^{159}$ Federal procedure can overlap with state outcome-determinative law; it can even overlap with state law that is truly substantive. A state might, for instance, create a cause of action with statutory damages but then, in order to prevent annihilative liability, provide that those damages are not available in class actions. That is a substantive purpose - it is a limit on the claim that is intended to operate in any forum-but it overlaps with federal procedural rules about the certification of class actions in federal court. ${ }^{160}$ It is these overlaps that make Erie analysis so complicated and confusing.

Once again, I suggest, the two-step model offers a better way. From that perspective, the key Erie questions are simply those of scope and priority. Does state law grant rights to the parties, even in a federal court? (This question should be answered by inquiring into the state law's purpose and asking whether that purpose will be promoted by its application in federal court.) Does federal law grant contrary rights? If so, which should prevail? (Federal law will prevail if the federal government wishes it to, but it might decide, for policy-Erie reasons, to yield or incorporate.) These questions may be hard to answer in some cases, but they are the right ones to ask. Next we will apply this understanding to some difficult Erie puzzles.

1. Statutes and the Constitution vs. Judge-Made Law.-Thinking about Erie in terms of scope and priority allows us to make sense of perhaps the most puzzling wrinkle that has arisen in the doctrine: the differential treatment of federal law depending on its source. If the federal law at issue in an Erie analysis is the Constitution, a statute, or a Federal Rule of Civil Procedure, it will be given effect as written. But when the federal law is judge made, the outcome is far less certain. In Walker $v$. Armco Steel Corp.,${ }^{161}$ for instance, and more recently in Gasperini v. Center for Humanities, Inc., ${ }^{162}$ federal law made by judges to fill gaps in the Rules either gave way (as in Walker) or melded with state law (as in Gasperini).

Whatever one thinks of the precise result the Court selected (Gasperini in particular has drawn its share of criticism ${ }^{163}$ ), the pattern is undeniable:

\footnotetext{
159 See Hanna v. Plumer, 380 U.S. 460, 469-72 (1965).

${ }^{160}$ I describe here roughly the facts of Shady Grove Orthopedic Assocs., P.A. v. Allstate Insurance Co., 130 S. Ct. 1431 (2010), which I discuss in more detail infra Part III.E.

161446 U.S. 740 (1980).

162518 U.S. 415 (1996).

163 See, e.g., Earl C. Dudley, Jr. \& George Rutherglen, Deforming the Federal Rules: An Essay on What's Wrong with the Recent Erie Decisions, 92 VA. L. REV. 707, 707-18 (2006) (calling Gasperini puzzling); C. Douglas Floyd, Erie Awry: A Comment on Gasperini v. Center for Humanities, Inc., 1997 BYU L. REV. 267, 271 ("[N]o careful reading of the Court's previous decisions or of the policies underlying Erie and the Rules of Decision Act could justify the bifurcated approach ... adopted by the
} 
judge-made law gets treated differently. But why? Federal common law, in the post-Erie world, is real federal law. ${ }^{164}$ It creates federal question jurisdiction and it can preempt state law just like a federal statute or the Constitution. ${ }^{165}$ Why should it be more yielding in Erie analysis?

The two-step model provides the answer. A court's task, on this model, is to determine the scope of the two competing laws and assign one priority if necessary. The Constitution itself asserts its priority in the Supremacy Clause, so if the case falls within its scope-if it creates rights or obligations - it must be given priority. ${ }^{166}$ So too for federal statutes, which the Supremacy Clause includes in its list of supreme law: they will always take priority over state law, unless Congress directs otherwise. ${ }^{167}$ The qualification is important: the Supremacy Clause gives federal lawmakers the power to preempt state law, but of course they can always decline to do so, as Congress occasionally has. ${ }^{168}$ Federal judge-made law differs from statutes not in terms of its potential preemptive force, but with respect to this decision as to whether or not to assert priority. With statutes, judges apply the law but do not make it. Thus, on the issue of priority vis-à-vis state law, they must simply enforce the decision Congress has already made. With judge-made law, however, they make the law and are free to make the priority decision on their own. ${ }^{169}$ This judicial discretion is presumably what the Hanna court had in mind when it referred to "the typical, relatively unguided Erie choice" as distinguished from the situation where "the court has been instructed" what to do. ${ }^{170}$ Without legislative guidance, the priority determination is a policy decision, and unsurprisingly judges have been guided by policy Erie in deciding the extent to which their

majority in Gasperini."); Richard D. Freer, Some Thoughts on the State of Erie after Gasperini, 76 TEX. L. REV. 1637, 1641 (1998) ("Although the Court's conclusions are reasonable, the road to them is not well lighted."); Hazard, supra note 129, at 1635 (calling Gasperini “a pitiful attempt").

164 See Henry J. Friendly, In Praise of Erie-and of the New Federal Common Law, 39 N.Y.U. L. REV. 383, 405 (1964).

165 See, e.g., Illinois v. City of Milwaukee, 406 U.S. 91, 98-100 (1972) ("[Section] 1331 jurisdiction will support claims founded upon federal common law as well as those of a statutory origin."); Banco Nacional de Cuba v. Sabbatino, 376 U.S. 398, 424-27 (1964) (holding that the federal common law act of state doctrine has preemptive force).

166 See U.S. CONST. art. VI, cl. 2.

${ }^{167} \mathrm{Id}$.

168 See, e.g., 15 U.S.C. § 1012(b) (2006) (disclaiming preemption of state insurance regulation).

169 More precisely, this is true of courts the first time they confront the issue, which is when they engage in the lawmaking. In subsequent cases, the law and the decision as to its priority have been made, and they will presumably follow the earlier decision either as a matter of stare decisis (if it is the same court) or binding precedent if a higher court has rendered a decision. Cases like Walker and Gasperini are examples of the Supreme Court's first encounter with the question of the priority of a particular judge-made rule vis-à-vis state law.

${ }^{170}$ Hanna v. Plumer, 380 U.S. 460, 471 (1965). Congress has indeed given the Court guidance as to how to apply the Federal Rules of Civil Procedure, but I will suggest below that the Court may have misunderstood that guidance. See infra Part III.C.2. 
judge-made rules should displace otherwise-applicable state law. That is exactly the reasoning we see in Walker and Gasperini. ${ }^{171}$

2. Federal Rules of Civil Procedure and State Substantive Law.-And what about the Federal Rules of Civil Procedure? The Court, as noted above, has treated them essentially like statutes, and most commentators have too: if a valid Federal Rule is on point, it must be given effect. ${ }^{172}$ A Rule is valid if the matter it regulates is "arguably procedural." ${ }^{\prime 173}$ Hence any Rule that regulates an arguably procedural matter will displace contrary state law, regardless of whether the state law would be deemed substantive. ${ }^{174}$ And as a practical matter, first-year students learn, you can be pretty confident that a Federal Rule of Civil Procedure is at least arguably procedural; not one has ever been struck down on the grounds that it strayed impermissibly into substance. ${ }^{175}$ As the Court put it in Hanna v. Plumer, when a Federal Rule is on point, "the court has been instructed to apply the Federal Rule, and can refuse to do so only if the Advisory Committee, this Court, and Congress erred in their prima facie judgment that the Rule in question transgresses neither the terms of the Enabling Act nor constitutional restrictions." 176

But this is a strange approach, as John Hart Ely and others have noted, because it seems to neglect a clearly significant provision of the Rules Enabling Act. The "arguably procedural" limit comes from 28 U.S.C. $\S 2072$ (a), which gives the Court power to make rules on procedural matters but does not mention substantive law. ${ }^{177}$ The following Section, however, adds another limit: the Rules "shall not abridge, enlarge or modify any substantive right." 178 This looks like a different kind of restriction. As Ely puts it, "The Act therefore contains ... limitations of both the checklist and

171 See Gasperini v. Center for Humanities, Inc., 518 U.S. 415, 430-31 (1996) (discussing Erie's “twin aims"); Walker v. Armco Steel Corp., 446 U.S. 740, 752-53 (1980) (noting that policy Erie seeks to prevent forum shopping).

172 See, e.g., Clark, supra note 38 at 1311 (“[W]hen Congress... adopts a federal rule on point... the only question for the judiciary is whether the particular rule falls within Congress's constitutional power to enact. If so, the Supremacy Clause instructs courts to follow the federal rule notwithstanding contrary state law, whether characterized as 'substantive' or 'procedural."' (footnote omitted)).

173 Hanna, 380 U.S. at 476 (Harlan, J., concurring) (internal quotation mark omitted).

174 Id. at 472 (majority opinion).

175 Dudley \& Rutherglen, supra note 163, at 739.

176380 U.S. at 471.

17728 U.S.C. § 2072(a) (2006) ("The Supreme Court shall have the power to prescribe general rules of practice and procedure and rules of evidence for cases in the United States district courts (including proceedings before magistrate judges thereof) and courts of appeals.”).

${ }^{178}$ Id. $\S 2072(\mathrm{~b})$. 
enclave variety." ${ }^{\prime 79}$ Not only is the Court's power limited in scope to procedural matters (the checklist), but within that scope, certain areas are carved out (the enclave) - subsection (b) says that even procedural rules are not to affect substantive rights.

Why should this language be ignored? One answer might be that the "arguably procedural" test actually incorporates the requirements of subsection (b) as well as those of subsection (a). ${ }^{180}$ If a Rule is procedural, this argument goes, then ipso facto it will not modify substantive rights; subsection (b) is mere surplusage. This argument would be sound if substance and procedure were mutually exclusive, nonoverlapping categories into which rules could be placed by abstract, context-independent analysis. But they are not; that view is exactly what sophisticated legal minds have been rejecting since at least the 1930s. ${ }^{181}$ And given that federal procedural law can in fact overlap with state substantive law, ${ }^{182}$ the "arguably procedural" test works only to ensure that the rule falls within the "checklist" restriction of authority to procedural matters. As to the "enclave" restriction, Hanna's invocation of the Advisory Committee, Congress, and the Court begs the question. None of those entities is in a position to decide whether applying the rule in a particular case will modify a substantive right, for the obvious reason that they have no way to foresee that case.

Another possibility is that whatever benefits the first sentence of subsection (b) grant to state law are undone by the next sentence, which provides that "[a]11 laws in conflict with such rules shall be of no further force or effect after such rules have taken effect." ${ }^{183}$ But this sentence is

179 Ely, supra note 37, at 719. By "checklist" limitation, Ely means the grant of a limited power akin to the enumerated powers of Congress. By "enclave," he means something carved out from within a limited power.

180 See Stephen B. Burbank, The Rules Enabling Act of 1934, 130 U. PA. L. REV. 1015, 1108 (1982). Burbank suggests that since Erie was still four years away, federalism was not on the drafters' minds. $I d$. at 1109-10. But the revolution of 1935, with its acceptance of vastly greater federal power, was also a year away, and constitutional "enclave" federalism still had vitality. See Ely, supra note 37, at 701-02. Given that the Court was protecting state enclaves against congressional legislation, subsection (b) might have been understood to reaffirm the existence of similar enclaves against Court rulemaking. Burbank quotes the drafter's transmission letter as describing it as reaffirming that "Congress could not if it wanted to, confer upon the Supreme Court, legislative power," which seems consistent with this reading. See Burbank, supra, at 1073 \& n.260 (quoting Letter from the Hon. Albert B. Cummins to the Hon. William H. Taft (Dec. 17, 1923) (internal quotation marks omitted).

181 See Walter Wheeler Cook, "Substance” and "Procedure” in the Conflict of Laws, 42 YALE L.J. 333, 334-35 (1933); Main, supra note 66. The drafters of the Rules Enabling Act may have subscribed to this dichotomy, but that does not necessarily mean that we must try to adhere to a conceptual structure that no longer fits the facts as we see them. It is also faithful interpretation to make sense of the statutory language while recognizing that certain presuppositions of the drafters have proved false. See generally Lawrence Lessig, Erie-Effects of Volume 110: An Essay on Context in Interpretive Theory, 110 HARV. L. REV. 1785 (1997) (discussing the effects of changed context on interpretation).

182 See supra text accompanying notes 159-60.

18328 U.S.C. $\S 2072$ (b). 
most naturally read to be not about the interaction of the Rules with state law but instead about their interaction with federal laws. It affirms, as might otherwise not be clear, that valid Rules can displace prior inconsistent federal statutes-unlike, say, agency regulations, which cannot. ${ }^{184}$ But it cannot easily be read to be about preempting state law, because Congress surely did not intend the Rules to preempt state laws in state court, which would be the consequence of rendering them "of no further force or effect."

The most likely answer is instead that taking subsection (b) at face value seems to eviscerate the Rules, ${ }^{185}$ or at least to place them at the mercy of even a single state. If a Rule that modifies a substantive right is invalid, then it seems that a single state could void a Rule by enacting a substantive law in conflict with it - void the Rule, that is, in the sense that it could not be applied even in states without such conflicting laws, or in federal question cases. That result is surely intolerable, but it seems to be the consequence of taking subsection (b) at face value. And because taking subsection (b) seriously leads to such odd results, it is better to ignore it entirely.

Or so people seem to think. ${ }^{186}$ But once again, the two-step perspective shows that there is another alternative. We can read the Enabling Act's restriction as a statement about priority. The Federal Rules, the Act says on this reading, should not be given priority if they conflict with "substantive" law (which I would read as law intended to give rights regardless of forum). This selective subordination of a rule is not at all the same thing as voiding it entirely. The Rule would yield when faced with contrary substantive law. But it would still have effect in federal question cases, and also in other diversity cases where no state substantive right stood in its way. ${ }^{187}$

184 Indeed, this is how the Supreme Court has read it. See Sibbach v. Wilson \& Co., 312 U.S. 1, 10 (1941) (stating that the procedural rules that this Court promulgates, "if they are within the authority granted by Congress, repeal" a prior inconsistent procedural statute).

185 See Hanna v. Plumer, 380 U.S. 460, 473-74 (1965) ("To hold that a Federal Rule of Civil Procedure must cease to function whenever it alters the mode of enforcing state-created rights would be to disembowel either the Constitution's grant of power over federal procedure or Congress' attempt to exercise that power in the Enabling Act.").

${ }^{186}$ See, e.g., Dudley \& Rutherglen, supra note 163, at 738, 741 (describing the "central insight in Hanna" as "that the validity of a federal rule should be determined as a general matter, not through caseby-case reconsideration of whether in a specific context it 'abridge[d], enlarge[d] or modif[ied] any substantive right"" and suggesting that if a challenge to a federal rule were to succeed, "the rule (or some severable provision within it) would be held invalid in its entirety and the task of revising the rule and narrowing its scope would be returned to the rulemaking process" (alterations in original) (quoting $\S 2072(b))$.

187 This lack of uniformity would come at some cost in terms of judicial workload. See Shady Grove Orthopedic Assocs., P.A. v. Allstate Ins. Co., 130 S. Ct. 1431, 1447 (2010) (plurality opinion) (arguing that case-specific analysis would be too costly). But it seems to be the most straightforward reading of the text. In Shady Grove itself, five Justices seemed to endorse the independent significance of the "shall not abridge" language, though they never formed a majority for this proposition. Id. at 1452-53 (Stevens, J., concurring); id. at 1463-64 \& n.2 (Ginsburg, J. dissenting). 
This is in fact close to the result the Court has reached in those cases where it has read a rule narrowly to avoid a conflict with state law, such as Walker, and arguably Gasperini and Semtek as well. In those cases, "the Court gave a Federal Rule an artificially narrow reading to avoid a conflict with state law on state claims but preserved a literal reading of the rule for federal claims." 188 Dudley and Rutherglen, like most other commentators, suggest that this must be wrong - the decisions giving the Rule one meaning in diversity actions and another in federal question ones "cannot stand together." 189 But this simply fails to see the consequence of the twostep model. It is true that a Federal Rule should not be interpreted differently in a diversity case than in a federal question case. ${ }^{190}$ But the Rule might well have a different effect if in one case it encounters a state substantive right and in the other it does not. ${ }^{191}$ Thus, thinking about the significance of the source of federal law from the perspective of the twostep model offers several benefits. It explains why judge-made law is different from statutory law for Erie analysis: because judges are empowered to make the priority decision with respect to the former but not the latter. It gives a clearer view of how to give meaning to the whole of the Rules Enabling Act: give priority to state substantive law when it conflicts with federal procedure. And it supports the Court's practice of giving Rules different effect in diversity cases and federal question cases: this can be understood as giving priority to state substantive law as subsection (b) of the Enabling Act directs, not as giving the Rules a different meaning.

\section{The Class Action Fairness Act}

Enacted in 2005, the Class Action Fairness Act of 2005 (CAFA) ${ }^{192}$ grants federal jurisdiction over, and hence allows removal of, class actions where minimal diversity exists between the opposing parties and the amount in controversy exceeds $\$ 5$ million. ${ }^{193}$ Federal courts hearing such cases must frequently deal with the interaction of choice of law and the

188 Dudley \& Rutherglen, supra note 163 , at 736.

189 Id. at $735-36$.

190 See Walker v. Armco Steel Corp., 446 U.S. 740, 750 n.9 (1980); Dudley \& Rutherglen, supra note 163 , at $734-36$.

191 Consider by way of comparison a state law that in one case is the only potentially applicable law and in another is preempted by federal law. Its effect in the two cases will certainly be different, but this is not because the state law has been interpreted differently or means one thing in one case but something different in the other.

192 Pub. L. No. 109-2, 119 Stat. 4 (codified in scattered sections of 28 U.S.C. (2006)).

19328 U.S.C. $\S 1332$ (d)(2) (2006). Other subsections of $\S 1332$ withdraw minor elements of this grant. See, e.g., id. §1332(d)(4)(B) (excluding classes in which at least two-thirds of plaintiffs and all primary defendants are citizens of the state in which the action was filed). 
class action form. ${ }^{194}$ The primary significance of choice of law for class actions is that courts often rely on choice-of-law analysis to decline to certify a nationwide class. If different class members' claims would be governed by different states' laws, courts frequently conclude that the suit fails to meet the predominance requirement of Federal Rule of Civil Procedure 23(b): if multiple states' laws will be used, common issues will not predominate over individualized ones. ${ }^{195}$

How should federal courts deal with choice of law in the class action setting? The most obvious answer is that they should do whatever state courts would do, on the grounds that this is what Klaxon directs. There is, I will suggest, considerable merit to this obvious response. But it is also incomplete in some important respects, and to get a fuller answer we need to think about the practice in state courts before CAFA and what its drafters hoped to achieve.

We may conveniently start with the latter. CAFA's "Findings and Purposes" section opens with the statement that "[c]lass action lawsuits are an important and valuable part of the legal system when they permit the fair and efficient resolution of legitimate claims of numerous parties . . ." ${ }^{196}$ But it is relatively clear that CAFA's drafters came not to praise class actions but to bury them. There follows a litany of complaints about alleged "abuses of the class action device that have-(A) harmed class members with legitimate claims and defendants that have acted responsibly; (B) adversely affected interstate commerce; and (C) undermined public respect for our judicial system." ${ }^{197}$ In particular, subsection (a)(4) observes:

State and local courts are-(A) keeping cases of national importance out of Federal court; (B) sometimes acting in ways that demonstrate bias against outof-State defendants; and (C) making judgments that impose their view of the law on other States and bind the rights of the residents of those States. ${ }^{198}$

CAFA provides federal jurisdiction, the findings and purpose section concludes, to "restore the intent of the framers of the United States Constitution by providing for Federal court consideration of interstate cases of national importance under diversity jurisdiction." 199

\footnotetext{
194 See generally Silberman, supra note 90 (analyzing the role of choice of law in selecting a forum to hear a class action and the effect of choice of law on interstate forum shopping in nationwide class litigation).

${ }^{195}$ See, e.g., In re Bridgestone/Firestone, Inc., 288 F.3d 1012, 1015 (7th Cir. 2002) ("No class action is proper unless all litigants are governed by the same legal rules. Otherwise the class cannot satisfy the commonality and superiority requirements of Fed.R.Civ.P. 23(a), (b)(3).").

196 Class Action Fairness Act $\S 2(a)(1)$.

197 Id. § 2(a)(2)(A)-(C).

198 Id. § 2(a)(4)(A)-(C).

199 Id. § 2(b)(2).
} 
To what extent were these concerns grounded in reality? ${ }^{200}$ It is true that prior to CAFA, state courts did sometimes decide that a single state's law could govern a nationwide class action, while federal courts had grown increasingly hostile to the practice. ${ }^{201}$ But to decide whether the state courts were acting abusively, we need a more fine-grained analysis. In particular, it is worth distinguishing between three possibilities.

First, if a Kansas court announces that it will decide a nationwide class action under Kansas law when the only contact is that some plaintiffs are from Kansas and were injured there-such that some other claims have absolutely no connection to the state-it has clearly behaved badly. Deciding that Kansas law will govern all the claims is an unconstitutional power grab by Kansas, projecting its law into cases where it has no authority. Second, if a Kansas court announces that it will decide a nationwide class action under Nebraska law when the only contact is that some plaintiffs are from Nebraska and were injured there, it is still behaving badly. It is violating the Constitution by deciding claims that have no connection to Nebraska under Nebraska law. The decision does not, however, look like a power grab by Kansas, ${ }^{202}$ the problem is that Nebraska law is arbitrary with respect to claims that have no contact to Nebraska. Third and last, if a Kansas court announces that it will decide a nationwide class action under Iowa law when Iowa is the defendant's principal place of business, or where the design or manufacture of a defective product took place, the Kansas court is quite likely not behaving badly. It has not violated the Constitution by deciding claims under the law of a state with no connection to the underlying facts, and it has not made a grab for power by unreasonably elevating its own law over that of other states.

To read CAFA's findings, you would think that state-court certification of nationwide classes followed the first of these three patterns-the unconstitutional power grab. But in fact that sort of thing has not gone on since the Supreme Court pronounced it unconstitutional in Phillips Petroleum Co. v. Shutts. ${ }^{203}$ Instead, decisions announcing that all claims will be subject to a single law uniformly follow the third pattern: they choose

\footnotetext{
${ }^{200}$ Stephen Burbank characterizes the findings and statement of purpose as either "window dressing" or "bullshit." Stephen B. Burbank, Aggregation on the Couch: The Strategic Uses of Ambiguity and Hypocrisy, 106 CoLUM. L. REV. 1924, 1942 (2006) (internal quotation marks omitted).

201 Compare Bridgestone/Firestone, 288 F.3d at 1015 (refusing to certify class on choice-of-law grounds), with Ysbrand v. DaimlerChrysler Corp., 81 P.3d 618, $627-29$ (Okla. 2003) (certifying nationwide class under Michigan law).

${ }^{202}$ At least not in the sense of asserting priority for its law. If Kansas makes itself a magnet forum for class actions, it has grabbed power in a different sense, which may be objectionable but is not the focus of this Article.

203472 U.S. 797, 821-22 (1985).
} 
the law of the defendant's principal place of business or the state where the defendant engaged in some relevant act. ${ }^{204}$

What is wrong with that? The main objection is that a court doing this may be reaching a different choice-of-law result for a class action because it is a class action, or engaging in what Richard Nagareda called "bootstrapping." 205 That is, the court might decide that a single state's law should govern the entire action when, had the claims been brought individually, it would have decided them under multiple different laws. ${ }^{206}$

On its face, this might seem bad. The principle that the procedural device of the class action should not alter substantive rights has significant intuitive appeal. ${ }^{207}$ In federal courts, it seems a plausible consequence of the Rules Enabling Act's admonition that the Federal Rules should not alter substantive rights. ${ }^{208}$ And a state court that disregards it might fairly be described as abusive if by so doing it deprives a defendant of the benefits of law it could have asserted against an individual suit.

But matters are a little more complex than that. To understand how choice of law works in a class action, we need to go back to the two-step model. Suppose we are dealing with a multistate products liability case. The defendant, operating in its principal place of business in Iowa, has manufactured goods that are then shipped and sold nationwide, and cause injuries in all of the states where they are purchased. And, for simplicity's sake, let us assume that the injured parties purchase the products and are injured in their domiciliary states, and that choice of law is the only possible obstacle to certification. Plaintiffs seek to certify a nationwide class. How should this be analyzed?

The first step is to ask which states' laws give the parties rights. Iowa law probably gives the plaintiffs a cause of action. It is not constitutionally required to do so, and statutory language or judicial construction might indicate that it does not (the statute might, for instance, specify that it applies "to all goods purchased in this state," or courts might have so construed it). But states typically do assert an interest in regulating the behavior of their corporate domiciliaries, even when the immediate

204 See, e.g., Ysbrand, 81 P.3d at 625-26 (law of defendant's principal place of business); David Marcus, Erie, the Class Action Fairness Act, and Some Federalism Implications of Diversity Jurisdiction, 48 WM. \& MARY L. REV. 1247, 1283 (2007) (noting that when courts choose a single state's law to apply to all class members' claims, it is usually the law of the defendant's principal place of business or the law of the state where a product was manufactured or designed).

205 See Richard A. Nagareda, Bootstrapping in Choice of Law After the Class Action Fairness Act, 74 UMKC L. REV. 661, 661 (2006).

206 Id. at 661-62.

207 See Kramer, supra note 123, at 572 ("Stated this way, the point seems both obvious and irrefutable.").

20828 U.S.C. $\$ 2072($ b) (2006). 
consequences of that behavior are felt out of state. ${ }^{209}$ (In products liability cases, for instance, states might want to ensure that local companies that follow good design and manufacture practices are not forced out of business by competition from those that do not.) Likewise, Iowa will give the defendant a defense - it presumably has an interest in seeing that the local defendant is not subjected to any greater liability than local law deems appropriate.

What about the plaintiffs' home state laws? As the place of injury and plaintiffs' domicile, these states surely give the plaintiffs causes of action. And again, correlatively, they will probably give the defendant a defense against greater liability (I will discuss this issue in more detail later). This first step of the two-step analysis lets us see clearly what is wrong with the two unconstitutional practices mentioned above (the Kansas court deciding all claims against an Iowa manufacturer under either Kansas or Nebraska law). In each case, the court would be deciding some claims under laws that do not, in fact, grant the plaintiffs any rights. (Neither Kansas nor Nebraska law has anything to say, for instance, about a Kentucky plaintiff injured in Kentucky by the Iowa manufacturer's product. ${ }^{210}$ )

So the first step of the two-step model can give us a better understanding of why courts cannot do what the Supreme Court has already forbidden - apply a single state's law when some class members' claims have no connection to that state. To figure out what is permissible, we need to move on to the second step. The court must decide whether these various rights (the claims and defenses) conflict, and if so, which is to be given priority. The class will be certifiable if the court decides that claims from a single state (which must be Iowa, as that is the only state that gives claims to all plaintiffs) should prevail over any defenses the defendant can assert.

The possible defenses are those created by the plaintiffs' home laws. Of course, the defendant can also invoke defenses from Iowa law, but because that law creates the plaintiffs' claims, those defenses do not create any problem of disuniformity that would threaten class certification. Here we need to distinguish two possibilities. A plaintiff's home law (or a particular aspect of that law) might be more plaintiff-friendly or it might be more defendant-friendly. That is, it might grant the plaintiff rights beyond what the Iowa law does (treble damages, say, or the availability of punitives, or a lesser burden of proof), or it might grant the defendant additional rights.

\footnotetext{
209 See, e.g., State ex rel. Corbin v. Pickrell, 667 P.2d 1304, 1312 (Ariz. 1983) (“Indeed, it would appear that the state has a legitimate interest in redressing the wrongs committed from within Arizona. There is a moral imperative to provide redress for those injured.").

${ }^{210}$ Interestingly, this constitutional problem is exactly the same problem that existed in Erie: deciding a claim under a law that does not create rights or obligations. See supra text accompanying note 49 .
} 
In the former case, the two-step perspective tells us something very important that the traditional view of choice of law obscures. When the plaintiff's home law is more plaintiff-friendly, there is in fact no choice-oflaw question presented. Such a plaintiff has a variety of rights that she could assert, some under her home state's law and some under Iowa law. As master of her complaint, she is entitled to assert whichever ones she wants, just as she would be entitled to choose to pursue a tort theory rather than a contract one, or one of several different causes of action available. If she wants to assert claims under Iowa law because that allows class certification, rather than claims under her home state's law, that is a permissible choice - and it is more election of remedies than choice of law.

So if plaintiffs whose home state's laws are more plaintiff-friendly wish to assert claims under Iowa law in order to join a class action, choice of law should be no obstacle. ${ }^{211}$ This is, as I said, an insight that the conventional understanding of choice of law obscures because rather than asking which rights the plaintiff wants to assert, it would simply try to decide which state's law applies. ${ }^{212}$ It is also an example of the choice-oflaw analysis coming out differently because of the class action device. If these claims were litigated individually, plaintiffs with more favorable home law would presumably want to pursue those claims rather than proceed under Iowa law, and a court might find that the rights created by the plaintiffs' home laws should prevail. Thus, those claims would be decided under the plaintiffs' home laws if brought individually, but under Iowa law in a class action. But, importantly, it is not an impermissible form of bootstrapping: what has changed is not the court's analysis of the scope or priority of state-created rights, but rather the plaintiff's litigation strategy.

What about the other possibility, where the plaintiff's home state's law is more favorable to the defendant? One might simply say that these defenses are not available to the defendant. The plaintiff's home state must surely offer them so far as claims under its law are concerned. If, for instance, the plaintiff seeks to recover under Kansas products liability law, the defenses under that law must be available to an Iowa defendant manufacturer-Kansas cannot withhold rights under its law simply because a defendant hails from another state. ${ }^{213}$ But it is not obvious that Kansas is required to give those defenses to an Iowa manufacturer in order to relieve

211 There are some slightly difficult questions here about whether joining a nationwide class and forgoing their home-state law claims is in the best interest of these plaintiffs — after all, they might be able to pursue a single-state class action. But these questions are actually relatively familiar from the class action context - they are analogous to those posed by a subset of plaintiffs who have additional claims that would be relinquished by joining the class. They are not choice-of-law questions.

212 I believe that framing the choice-of-law question this way-as "what law applies?"-is responsible for a significant portion of the confusion attending the field of conflict of laws. See Roosevelt, Renvoi, supra note 6, at 1887-88.

213 See Roosevelt, Myth, supra note 6, at 2512. 
it of liability that Iowa law imposes. And because doing so would simply disfavor an injured Kansas domiciliary, one might conclude that Kansas policy would be to withhold those defenses. ${ }^{214}$ If so, there is no conflict of rights here either, in which case certification of a class under the defendant's home law would be almost always appropriate.

However, that might not be the best interpretation of Kansas law. It might also be the case that Kansas offers defendants various protections not just to encourage companies to manufacture goods in Kansas (the obvious reason for defendant-friendly products liability laws), but also to encourage out-of-state companies to ship goods into Kansas. That purpose would be served by granting the Kansas defenses to an Iowa manufacturer, and even by granting them again against Iowa claims.

Then we would have what modern choice-of-law theorists call a true conflict: each state's law grants rights, the rights conflict, and the court must give one priority. If the court decided that the Iowa law should get priority, the class could still be certified and all claims could be decided under Iowa law. If it decided that the plaintiff's home state's law should get priority, plaintiffs from that state would not be able to join the class. And this is where the possibility of questionable bootstrapping arises: in making this priority decision, a court might change its analysis because the case was brought as a class action. It might, that is, decide to give priority to Iowa law for the class action even though it would have given priority to the plaintiff's home state law in an individual suit. ${ }^{215}$

Thus, we must consider CAFA's effect on three possible scenarios:

- The state court, not engaging in bootstrapping, would decline to certify the class on the grounds that some claims should be decided under the plaintiffs' home laws - that is, it would decide that the defenses given by those laws were available to the defendant and should prevail over rights under Iowa law;

- The state court, not engaging in bootstrapping, would certify the class on the grounds that all claims should be decided under Iowa law - that is, it would decide either that defenses under the plaintiffs' home laws were not available to the Iowa defendant, or that Iowa rights should take priority;

- The state court would certify the class because it engaged in bootstrapping to decide that all claims should be governed by Iowa law-that is, although in an individual case it would

\footnotetext{
214 See, e.g., Downing v. Abercrombie \& Fitch, 265 F.3d 994, 1007 (9th Cir. 2001) (describing idea that state has an interest in preventing recovery by a domiciliary as "pure fancy").

215 Nagareda, supra note 205, at 672-75, argues persuasively that state courts tend to do this by finding that the defendant's principal place of business stands out as compared to the many other states implicated in a class action - a line of reasoning obviously not available in individual cases.
} 
have given priority to the plaintiff's home law, it would give priority to Iowa law because the case is a class action.

How should these cases come out if removed to federal court under CAFA? The first case is easy. It is also somewhat unlikely to make it to federal court-if the state court will refuse to certify a class, and the defendant can foresee that outcome, there is no reason to remove it. But if such a case does wind up in federal court, the federal judge should follow his state counterpart and also decline certification. The state court has decided to give the plaintiffs' home laws priority over Iowa law. I have argued that federal courts are independent on priority questions, but for policy-Erie reasons, they should usually follow state rules of priority. ${ }^{216}$ This situation provides no reason to depart from that general rule.

The second case, where the state court would certify without bootstrapping, is a little more complicated. The immediate response might be that this is a choice-of-law decision, and Klaxon tells federal courts facing choice-of-law issues to follow the courts of the states in which they sit - hence the federal court should also certify the class. But a more precise analysis discloses several wrinkles. For one thing-and this is one of CAFA's very significant effects - it might be the case that statecertification requirements are more lenient than those of Rule $23 .{ }^{217}$ In some substantial number of cases, classes that would have been certified under state procedure will fail the more demanding test of Federal Rule 23 . $^{218}$

That is a significant effect, and it must be noted, but it is not a choiceof-law issue. So what about the choice-of-law based certifications? Should the federal court follow the state court and certify the class on the grounds that every claim can be decided under Iowa law?

There are, I said, two different ways the state court could have reached this conclusion. First, it might decide that the defendant simply cannot claim rights under the plaintiffs' home law, because it believes that those states do not intend to grant rights to such defendants. If this decision is correct, then the federal court should also certify the class. This, again, is the same kind of situation as Erie itself: Iowa law grants the plaintiffs a cause of action and no other state's law grants the defendant defenses, so Iowa law is the only law under which the claims can be decided. But how do we know that the decision is correct? The state court is not determining the scope of its own law (on which it is authoritative); it is determining the scope of other states' laws. On that question it is not authoritative, and the

\footnotetext{
${ }^{216}$ See supra text accompanying notes 97-109.

217 Under Arkansas law, for instance, courts are not required to perform a choice-of-law analysis before certifying a nationwide class. See Gen. Motors Corp. v. Bryant, 285 S.W.3d 634, 641 (Ark. 2008).

218 In Arkansas, for instance, any case that could not be certified because different class members' claims will be governed by different laws will not be certified in federal court but will-assuming it meets the other requirements - in state court.
} 
federal court might believe that the state court has made a mistake in its construction of the other states' policies. What should it do then?

There are policy-Erie reasons to follow the state court anyway, but they are not as weighty as policy Erie usually is. In the ordinary case, the policy-Erie point that offering a different result in federal court is unfairly favorable to the out-of-stater who can invoke diversity jurisdiction is supported by two considerations: the inherent unfairness of giving out-ofstaters the possibility of different results in federal court, and the lack of any federal interest or other good reason for doing so. But in this case there is a good reason: the federal court thinks that the state court has gotten sister-state law wrong. Whether this reason should be weighty enough is hard to say - it depends on how blatant the state court's error is, and most times the desire for uniformity will probably prevail. In some circumstances, though, a mistaken construction of sister-state law might be severe enough that it should not be followed in federal court.

The second reason that a state court might certify the hypothetical class under Iowa law is that, without bootstrapping, it has decided that although the rights created by Iowa law conflict with those created by the laws of the plaintiffs' home states, Iowa law should get priority. Should the federal court follow this determination?

This is a relatively straightforward Klaxon question: should a federal court follow state rules of priority? I've said already that while federal courts are independent on questions of priority (which they are not on questions of scope), policy Erie will ordinarily suggest that they should follow their state counterparts. Exceptions might arise when a state is unreasonably discriminatory in giving priority to its law over foreign law, but that situation does not exist in this hypothetical. Most suits would presumably be brought in states other than Iowa, so forum law would not get priority, and even for suits brought in Iowa, the priority determination would be reasonable. So in an ordinary diversity suit, the federal court should follow the state court and certify the class.

Does CAFA change the analysis? Congress clearly has the power under the Full Faith and Credit Clause to tell federal courts to follow different rules of priority. ${ }^{219}$ And in enacting CAFA, Congress did seem to hope for some federal departures from state court practice. ${ }^{220}$ But in the text of the statute, it identified the occasions for such departures very much in terms of the unfair discrimination I have mentioned: state courts exhibiting

\footnotetext{
219 See, e.g., Gottesman, supra note 109, at 23 ("Scholars are virtually unanimous in their view that Congress has the power to enact federal choice of law statutes.").

220 The Senate Report on CAFA spoke disparagingly of state court decisions that certified nationwide classes under a single law and noted approvingly federal court decisions that refused to do so. See S. REP. No. 109-14, at 23-27, 63-64 (2005) ("By enabling federal courts to hear more class actions, this bill will help minimize the class action abuses taking place in state courts and ensure that these cases can be litigated in a proper forum.").
} 
"bias against out-of-state defendants" and "impos[ing] their view of the law on other States." 221 Those seem like fairly clear references to certifying classes under forum law and disregarding foreign defenses. Certifying classes under the law of the defendant's home state, especially when it is the not the forum, does not seem to raise the problems Congress listed. So CAFA should not make a difference here: if a state court, without bootstrapping, would certify the class under the defendant's home law, a federal court should too-or at least, it should not decline to do so on choice-of-law grounds. ${ }^{222}$

What happens when a state court bootstraps? In the absence of CAFA, it is not clear what a federal court should do. On the one hand, for a federal court to bootstrap on its own initiative seems wrong, as Larry Kramer has argued. ${ }^{223}$ Federal procedural rules are not supposed to change the parties' substantive rights, and changing rules of priority because a case is filed as a class action seems to do just that. On the other hand, if a federal court bootstraps because the state court would, it is state law and not federal procedure that is changing the substantive rights. So the federal prohibition against modifying substantive rights would not stand as a barrier.

But perhaps there is another obstacle. When a state court bootstraps, state procedural law is modifying the parties' substantive rights. The state rule for certification, the analog of Federal Rule 23, is being understood, at least implicitly, to authorize the court to depart from the choice-of-law analysis it would use if the claims were presented individually-to give priority to claims under the defendant's home law. But the Rules Enabling Act tells a federal court following Federal Rule 23 not to do this-not to alter the parties' substantive rights for procedural reasons such as the existence of a class action. ${ }^{224}$ So already there is a real tension between Klaxon and the Enabling Act.

Bring CAFA into the picture, and the matter becomes clearer. Congress was plainly concerned that state courts were certifying too many class actions, and it plainly was hoping that fewer would be certified in federal court. ${ }^{225}$ This is perhaps best understood as a limited repeal of policy Erie: in some cases, Congress appears to be saying, there is a good enough reason for federal courts to reach different results than state courts. What

\footnotetext{
${ }^{221}$ Class Action Fairness Act of 2005, Pub. L. No. 109-2, § 2(a)(4)(B)-(C), 119 Stat. 4, 5 (codified in scattered sections of 28 U.S.C.).

222 One could, of course, respond that CAFA's drafters plainly hoped to take advantage of federal judges' relative distaste for class actions, and that the findings and statements of purpose are disingenuous. See Burbank, supra note 200. But that attempt to change results through judicial predilection rather than statutory direction is deeply contrary to the spirit of Erie, see Marcus, supra note 204, at 1310-12, and hewing close to CAFA's stated justifications is an appropriate response.

223 See Kramer, supra note 123, at 549.

22428 U.S.C. $\$ 2072$ (b) (2006).

${ }^{225}$ See supra text accompanying notes 220-21.
} 
kind of cases? The text of the statute identifies some problems that do not really exist in state court practice, but we can infer an antipathy to changing choice-of-law analysis in order to facilitate certification. Given the doubt about whether a federal court should follow a bootstrapping state court at all, CAFA is a good enough reason to go the other way. ${ }^{226}$

Here the two-step model shows us the best form of the argument for certification under the defendant's home law: that this law creates a cause of action for the plaintiffs, who can, if they wish, waive more generous remedies offered by their own states' laws, or that the defendant's home law should prevail in a conflict with more defendant-friendly laws from the plaintiffs' home states. It also shows us what it would mean for a federal court to depart from state choice-of-law analysis: the federal court would be making a different decision as to the relative priority to be given to the defendant's and plaintiffs' home laws. Last, it explains when this departure would be appropriate: when the state court would certify the class only because it has engaged in bootstrapping.

\section{E. Shady Grove v. Allstate}

The Supreme Court's most recent venture into the Erie arena concerns not CAFA's fear of permissive certification practice in state courts, but actually the reverse: a claim that could not be heard as a class action in a state court but could - the Court concluded - in federal court. ${ }^{227}$ Shady Grove Orthopedic Associates sued Allstate Insurance in federal court for failing to pay an insurance claim on time. ${ }^{228}$ In such cases, New York insurance law entitles insured parties to statutory interest of two percent monthly. ${ }^{229}$ Shady Grove alleged that untimely payments were Allstate's practice and sought certification of a class of all persons to whom Allstate owed interest. ${ }^{230}$

New York Civil Practice Law section 901(b) provides that an action to recover statutory damages "may not be maintained as a class action." ${ }^{231}$ The question in Shady Grove was whether this New York rule prevented certification in federal court, or whether it should be deemed supplanted by the requirements of Federal Rule 23(b). ${ }^{232}$

\footnotetext{
${ }^{226}$ See Nagareda, supra note 205, at 683-85.

227 See Shady Grove Orthopedic Assocs., P.A. v. Allstate Ins. Co., 130 S. Ct. 1431, 1437 (2010) (plurality opinion). For another attempt to analyze this case from a choice-of-law perspective, see Joseph P. Bauer, Shedding Light on Shady Grove: Further Reflections on the Erie Doctrine from a Conflicts Perspective, 86 Notre DAME L. ReV. 939 (2011).

${ }_{228}$ Shady Grove, 130 S. Ct. at 1436.

${ }^{229} I d$.

${ }^{230}$ Id. at $1436-37$.

231 Id. at 1436 n.1 (internal quotation mark omitted) (quoting N.Y. C.P.L.R. 901(b) (McKinney 2006)).

${ }^{232}$ Id. at $1437-38$.
} 
The Court fragmented badly on that issue. Justice Scalia, joined by Justices Roberts, Thomas, and Sotomayor, found a "direct collision" between Rule 23 and section 901(b) and argued that in such case, the Federal Rule should prevail unless it was invalid under the Rules Enabling Act - a question to be determined by looking only at the Rule and asking whether it regulated procedure. ${ }^{233}$ This four-Justice plurality found the Rule valid under that test and held that it preempted section 901(b): the class could be certified. ${ }^{234}$

Justice Ginsburg, writing for herself and Justices Kennedy, Breyer, and Alito in dissent, wanted to give independent significance to the Rules Enabling Act's prohibition on the modification of substantive rights. Relying on choice-of-law theory, she would have adopted a moderate interpretation of Rule 23 and held that the class could not be certified to the extent that it sought statutory damages. ${ }^{235}$

Justice Stevens, writing alone in concurrence, agreed with Justice Ginsburg that the Enabling Act's "shall not abridge" language should be given independent force. ${ }^{236}$ But because he thought the New York law did not deal with substantive rights, he agreed with Justice Scalia's disposition of the case and provided a fifth vote for certification. ${ }^{237}$

Shady Grove is a hard case to read in terms of its precedential significance. Justice Stevens joined the part of Scalia's opinion finding a direct conflict between Rule 23 and section 901(b), but he also seemed to disavow that part's claim that a Rule's validity is an all-or-nothing affair. ${ }^{238}$ Justice Ginsburg, for her part, argued in a footnote that "a majority of this Court... agrees that Federal Rules should be read with moderation in diversity suits to accommodate important state concerns. ${ }^{239}$ How the Court will read the Enabling Act in the future seems an open question, especially given the replacement of Justice Stevens by Justice Kagan.

Analytically, however, the case is actually relatively easy. The Justices split 5-4 over whether to give independent significance to the Rules Enabling Act's "shall not abridge" language, with five agreeing that they should ${ }^{240}$ : if section 901(b) was about the scope of substantive rights, Rule 23 would be forced to accommodate it. On the question of whether

\footnotetext{
${ }^{233} I d$.

234 Id. at $1447-48$.

235 Id. at 1460 (Ginsburg, J., dissenting).

${ }^{236}$ Id. at 1452-54 (Stevens, J., concurring).

${ }^{237}$ Id. at $1457-60$.

238 Compare id. at 1440-42 (plurality opinion) (criticizing Ginsburg's suggested case-by-case analysis), with id. at 1452 (Stevens, J., concurring) (endorsing a case-by-case analysis).

239 Id. at 1464 n.2 (Ginsburg, J., dissenting).

${ }^{240} \mathrm{Id}$.
} 
section 901(b) was substantive, however, Justice Stevens split from the four dissenters, giving Justice Scalia a fifth vote for the disposition. ${ }^{241}$

But even the 5-4 split over the Rules Enabling Act probably amounts to less than it seems in terms of underlying principles. We may see this by considering two different statutes that the New York legislature might have written. First, they could have written an unambiguously substantive one. Into each statute providing for statutory damages, they could have added a section providing, "Because these damages exist to provide an incentive for individual suits, they shall not be available to any plaintiff proceeding via a class action." Certainly the four dissenters and Justice Stevens would not have found a conflict between this statute and Rule 23, and most likely the four-Justice plurality would not have found a conflict either. ${ }^{242}$ Rule 23 does not purport to create remedies independent of those available under state law, and it is unlikely that either the Rules Enabling Act or the Constitution would allow it to do so. Shady Grove's class action might proceed, but it would be limited to actual damages and hence would likely not meet CAFA's amount-in-controversy requirement.

On the other hand, the legislature might have written an unambiguously procedural statute, a general provision stating, "Because class actions are burdensome for courts, no class action seeking statutory damages may be maintained in the courts of this state." Here again there would clearly be no conflict between Rule 23 and the state law, though the result would be that the class action seeking statutory damages would be allowed in federal court.

Which of these statutes was the legislature trying to write? Or did it have both a procedural and a substantive purpose in mind? How to construe this particular statute is not the main focus of this Article, though I think that Justice Ginsburg has the better of the argument. It is easy to see why the legislature might have wanted to exclude statutory damages from class actions: the effect of multiplying those damages across the class could produce annihilative liability. It is much harder to see why they might have wanted to allow such damages but exclude the actions from New York courts: there is nothing procedurally objectionable about them.

My main point is that thinking about these possibilities in terms of the two-step model brings more analytical clarity. Regardless of which statute the New York legislature intended to write, the case, like Erie itself, presents a false conflict: a situation where the relevant issue falls within the lawmaking power of only one sovereign. If the statute limits the recovery available to class action plaintiffs, then it is about the definition of rights under New York law, something within the sole authority of New York. ${ }^{243}$

\footnotetext{
${ }^{241}$ Id. at 1457-60 (Stevens, J., concurring).

242 See id. at 1439 n.4 (plurality opinion) (reserving the question).

243 The Court has endorsed this as the Erie principle, though without being explicit about whether it is constitutional or policy Erie. See, e.g., Ragan v. Merchs. Transfer \& Warehouse Co., 337 U.S. 530,
} 
If it is about requirements for class certification, then New York law controls in New York courts and Rule 23 controls in federal courts. No Justice disagreed with these propositions. Shady Grove is important because the way the Court interprets ambiguous state statutes will affect outcomes - and as Justice Ginsburg explains, Scalia's rather wooden textualism does not make much sense when trying to determine how a statute should operate in contexts the lawmakers did not contemplate. ${ }^{244}$ But once a method of interpretation is chosen, the analysis is straightforward.

\section{CONCLUSION}

I have tried elsewhere to demonstrate that thinking about choice-of-law problems from the perspective of the two-step model renders them much easier to resolve. ${ }^{245}$ Here I have argued the same thing about a variety of Erie problems. Because Erie is, I believe, fundamentally a choice-of-law case, that result should not be surprising. That the two-step model works so well here should buttress the case that Erie is best understood as a choiceof-law case. It should also enhance the appeal of the model itself. That is my ultimate aim - to demonstrate that this way of thinking about the general problem is superior to the approach that takes choice of law to be some sort of metaprocedure divorced from substantive law.

533-34 (1949) ("We cannot give [the cause of action] longer life in the federal court than it would have had in the state court without adding something to the cause of action. We may not do that consistently with Erie R. Co. v. Tompkins.").

244 See Shady Grove, 130 S. Ct. at 1469-70 (Ginsburg, J., dissenting).

245 See, e.g., Roosevelt, Renvoi, supra note 6; Roosevelt, Myth, supra note 6. 
N ORT H W ESTER N UN IVER S T Y L A W R E VIE W 